\title{
DETERMINING THE DIRECTIONS AND CHARACTERISTICS OF UNDERGROUND WATER FLOW IN KARST FOR THE PURPOSE OF TRAFFIC ROUTES CONSTRUCTION: THE CASE OF THE NEW DIVAČA-KOPER RAILWAY LINE (SW SLOVENIA)
}

\section{DOLOČITEV SMERI IN ZNAČILNOSTI TOKA PODZEMNE VODE V KRASU ZA NAMEN IZGRADNJE PROMETNIH POTI: PRIMER NOVE ŽELEZNIŠKE PROGE DIVAČA-KOPER (JZ SLOVENIJA)}

\author{
Metka Petrič ${ }^{1,2 *}$, Nataša Ravbar ${ }^{1,2}$, Luca Zini $^{3}$, Chiara Calligaris $^{3}$, Riccardo Corazzi ${ }^{4}$, \\ Zdenka Žitko ${ }^{5}$, Marco Restaino ${ }^{6}$ \& Martin Knez ${ }^{1,2}$
}

\begin{abstract}
UDC 556.34(497.47)
Metka Petrič, Nataša Ravbar, Luca Zini, Chiara Calligaris, Riccardo Corazzi, Zdenka Žitko, Marco Restaino \& Martin Knez: Determining the directions and characteristics of underground water flow in karst for the purpose of traffic routes construction: the case of the new Divača-Koper railway line (SW Slovenia)

The new railway line between Divača and Koper/Capodistria in south-western Slovenia is being built, a part of which crosses the southern outskirts of the Classical Karst plateaux. It will run through two tunnels, the northern tunnel T1 (6.7 km long) and the southern T2 (6 km long), which partially cross karst aquifer system. A multi-tracer test with injections of fluorescent dyes uranine and naphthionate, bypassing the karst vadose zone, was carried out to define the directions and dynamics of the underground water flow. The main goals were better understanding of the complex hydrogeological conditions in the area and assessment of possible environmental impacts on the nearby water sources. With tracing of uranine injected into a nearby cave stream, the direction of flow from the northern T1 tunnel mainly towards the Reka-Timavo aquifer system and further towards the Timava/Timavo springs was proved. The peak velocities, as determined from the peaks of the tracer breakthrough curves, range from $29 \mathrm{~m} / \mathrm{h}$ to $36 \mathrm{~m} / \mathrm{h}$. Through
\end{abstract}

\begin{abstract}
Izvleček
UDK 556.34(497.47)

Metka Petrič, Nataša Ravbar, Luca Zini, Chiara Calligaris, Riccardo Corazzi, Zdenka Žitko, Marco Restaino \& Martin Knez: Določitev smeri in značilnosti toka podzemne vode $v$ krasu za namen izgradnje prometnih poti: primer nove železniške proge Divača-Koper (JZ Slovenija)

Med Divačo in Koprom v jugozahodni Sloveniji je v izgradnji nova železniška proga, ki deloma seka južno obrobje planote matičnega krasa. Proga ima dva predora, severni T1 (dolg 6,7 $\mathrm{km}$ ) in južni T2 (dolg $6 \mathrm{~km}$ ), ki potekata skozi kraški vodonosnik. Za določitev smeri in dinamike toka podzemne vode je bil izveden kombinirani sledilni poskus z injiciranjem fluorescenčnih sledil uranina in naftionata neposredno v zasičeno cono. Glavna cilja sta bila boljše razumevanje zapletenih hidrogeoloških razmer na tem območju in ocena možnih okoljskih vplivov na bližnje vodne vire. $\mathrm{Z}$ injiciranjem uranina v vodni tok v bližnji kraški jami je bila dokazana smer toka podzemne vode $\mathrm{z}$ območja severnega predora $\mathrm{T} 1$ predvsem proti vodonosnemu sistemu Reka-Timava in naprej proti izvirom Timave. Glede na pojav vrha krivulje iztekanja sledila so bile določene navidezne dominantne hitrosti med $29 \mathrm{~m} / \mathrm{h}$ in $36 \mathrm{~m} / \mathrm{h}$. V večjih in dobro povezanih kraških kanalih sistema Reka-Timava lahko te hitrosti dosežejo $88 \mathrm{~m} / \mathrm{h}$. V Jami $1 \mathrm{v}$ Kanjaducah, ki je del sistema, je bilo zaznanih približno $74 \%$ injiciranega sledila.
\end{abstract}

\footnotetext{
${ }^{1}$ ZRC SAZU, Karst Research Institute, Titov trg 2, 6230 Postojna, Slovenia; metka.petric@zrc-sazu.si, natasa.ravbar@zrc-sazu.si, martin.knez@zrc-sazu.si

${ }^{2}$ UNESCO Chair on Karst Education, University of Nova Gorica, Glavni trg 8, 5271 Vipava, Slovenia

${ }^{3}$ Department of Mathematics and Earth Sciences, University of Trieste, Via Weiss 2, 34128 Trieste, Italy; zini@units.it, calligar@ units.it

${ }^{4}$ Caving club Commissione Grotte "E. Boegan” - Società Alpina delle Giulie CAI Trieste, via Donota 2, 34121 Trieste, Italy; corazzi@iname.com

${ }^{5}$ Speleological Association of Slovenia, Lepi pot 6, 1000 Ljubljana, Slovenia; tajnistvo@jamarska-zveza.si

${ }^{6}$ Caving club Società Adriatica di Speleologia, Via Rossetti 59A, 34141 Trieste, Italy; marco.restaino@yahoo.it

* Corresponding author
} 
the wider and well-connected conduits of the Reka-Timavo system, the peak velocities can reach up to $88 \mathrm{~m} / \mathrm{h}$. The recovery of uranine in an intermediate cave, i.e., Jama $1 \mathrm{v}$ Kanjaducah, amounted to approximately $74 \%$. The northern section of the southern T2 tunnel is a part of a wider bifurcation zone between the Osapska Reka and the Boljunec/Bagnoli springs, where peak flow velocities between 10 and $13 \mathrm{~m} / \mathrm{h}$ have been determined by tracing of naphthionate injected into a borehole located in the line of the planned tunnel. It has been estimated that about $25 \%$ of the injected naphthionate flew out through the Osapska Reka spring and about $5 \%$ through the Boljunec/ Bagnoli springs. Based on this research, proper monitoring of any potential negative impacts of the new railway line will be made possible. The study presents an approach to better planning of hazard control of traffic routes in complex and highly karstified rock settings.

Key words: karst water, railway route, tracer test, phreatic zone, active cave streams, Classical Karst.
Severni del južnega predora T2 je del širšega bifurkacijskega območja med Osapsko reko in izviri v Boljuncu. V njem so bile $\mathrm{z}$ injiciranjem naftionata $\mathrm{v}$ eno izmed vrtin $\mathrm{v}$ trasi načrtovane železniške proge ugotovljene dominantne hitrosti toka med 10 in $13 \mathrm{~m} / \mathrm{h}$. Ocenjeno je bilo, da je približno $25 \%$ injiciranega naftionata izteklo skozi izvir Osapske reke in približno $5 \%$ skozi izvire $\mathrm{v}$ Boljuncu. $\mathrm{Z}$ upoštevanjem rezultatov raziskave bo mogoč ustrezen monitoring morebitnih negativnih vplivov nove železniške proge na podzemne vode. Študija prinaša izboljšan pristop $\mathrm{k}$ načrtovanju nadzora nad nevarnostmi prometnih poti na območjih zelo zakraselih kamnin s prepletanjem podzemnih vodnih tokov.

Ključne besede: kraška voda, železniška proga, sledilni poskus, zasičena cona, aktivni vodni tokovi, matični kras.

\section{INTRODUCTION}

Karst aquifers contain large volumes of water, representing water resources of worldwide importance (Stevanović 2019). Due to their specific characteristics they are particularly vulnerable to various human activities on the surface. Traffic is one of the pollution sources that can jeopardize the quality of karst water. Water flowing off of roads and other paved surfaces can quickly percolate into the subsurface and further toward karst water sources (Hötzl 1999; Turpaud et al. 2018). Pollution can be constant due to continuous runoff or episodic (catastrophic) due to the spills of pollutants during traffic accidents. The latter represent an immediate hazard as spills can instantly release a large volume of pollutants (Kogovšek \& Petrič 2011), whereas the former may release lower concentrations into the karst system but for a prolonged period of time (Kogovšek 2011).

Moreover, when constructing surface or underground traffic structures in karst, several significant impacts have been encountered so far, such as water inrush in tunnels, or drying of springs and base-flow losses at mountain streams due to drilling, or engineering setbacks due to geomorphological and stability constraints (e.g., Alija et al. 2013; Li \& Li 2014; Vincenzi et al. 2014; Zini et al. 2015; Jin et al. 2016; Raithel et al. 2016).

As regards water-related issues, a karst-specific water inrush and runoff management plan should be prepared for each section of the traffic route before the construction takes place (Zhou \& Beck 2005). Furthermore, the monitoring of any potential negative impacts of its construction and operation should be based on a comprehensive analysis of the characteristics of groundwater flow (Gabrovšek et al. 2015). The standard methods of obtaining this information are numerical groundwater modelling, analytical and empirical approaches. These require diverse geological and hydrogeological input data, whose quality in karst mainly depends on their indirect acquisition and is prone to lower reliability due to high bedrock heterogeneity. Concurrently, these data are often affected by a high level of uncertainty, because they are generally scarce in quantity. Thus, the obtained results could be less reliable for predicting groundwater drainage patterns towards, along and from the proposed route. To most straightforwardly assess this information, tracer tests with artificial tracers are especially useful (Massei et al. 2006; Benischke et al. 2007; Goldscheider et al. 2008; Barberá et al. 2018).

This study focuses on the planning and construction of a new railway line between Divača and Koper/Capodistria (Slovenian/Italian name in the bilingual area) in south-western Slovenia, which will significantly improve the traffic connections between the Slovenian coast and the inland (Knez et al. 2019). Its section in the karst area, $12.7 \mathrm{~km}$ of which will run through tunnels, intersects the highly vulnerable trans-boundary karst aquifer of the Classical Karst, which is a strategic water resource for both countries: Italy and Slovenia (Urbanc et al. 2012). As the underground water network is highly branched and the recharge areas of a greater number of springs intersect there, several tracer tests have been conducted for this purpose. The article sums up the results of important previous tracer tests and details the results of the latest multi-tracer test, which was conducted in the autumn of 2018 with injection points inside the karst system.

As the tracer test was conducted in the cross-border 
Slovenian-Italian region and its implementation was very demanding due to the great number of sampling points and a few hard-to-reach injection and sampling points, several organizations were involved in its planning and implementation: Karst Research Institute ZRC SAZU,
Speleological Association of Slovenia, Department of Mathematics and Earth Sciences, University of Trieste, and the caving clubs Commissione Grotte "E. Boegan" and Società Adriatica di Speleologia from Trieste.

\section{MATERIALS AND METHODS}

\section{STUDY AREA}

The karst area, through which the planned new Divača Koper/Capodistria railway line will run, is characterized by an imbricate thrust structure, where bands of Eocene flysch (medium to low permeable layers on Fig. 1A) are interspersed among carbonate rocks - predominantly limestone of Upper Cretaceous, Palaeocene and Eocene age (well permeable layers on Fig. 1A). The surface karst features and the number of registered karst caves indicate well-karstified carbonate rocks and typical characteristics of karst aquifer systems. Flysch consists of very poorly permeable marls, silicate sandstones and breccias (Placer et al. 2010; Gabrovšek et al. 2015; Jurkovšek et al. 2016).

The flysch layers between karst aquifers present local hydrogeological barriers, along which water may accumulate and flow. The flysch rocks on the surface enable surface flows that sink into the underground at the contact with the karst. On the other hand, flysch also acts as a hydrological barrier which causes underground karst waters to discharge onto the surface in karst springs.

The route of the new railway runs from Divača about $3 \mathrm{~km}$ across the karst surface and then enters the northern tunnel (T1), $6.7 \mathrm{~km}$ long, which ends in the upper part of the valley of the Glinščica/Rosandra River. After a $250 \mathrm{~m}$ long bridge the railway enters the southern tunnel (T2), $6 \mathrm{~km}$ long. The last part of the second tunnel passes from the karst area to the viaduct and then runs almost entirely through tunnels across the flysch area to the Port of Koper/Capodistria. The route in karst mostly runs at a depth of about $200 \mathrm{~m}$ below the surface, in some sections it is more than $300 \mathrm{~m}$ deep. In case of very high water, the water table may rise above the planned railway line in some sections (Gabrovšek et al. 2015).

The northern part of the route intersects the area of the Classical Karst with the underground flow of the Reka River, which sinks from the surface into the Škocjanske jame caves approximately $3.5 \mathrm{~km}$ east of the route and then outflows in the spring belt between Nabrežina/ Aurisina and Timava/Timavo spring (the Reka-Timavo conduit system). In the 1989-2018 period, the hydro- logical station Cerkvenikov mlin (roughly $7 \mathrm{~km}$ ahead of the ponor) measured the lowest flow rate of the Reka River at $0.25 \mathrm{~m}^{3} / \mathrm{s}$, while the mean flow rate was $7.75 \mathrm{~m}^{3} / \mathrm{s}$ (ARSO 2020). During very high water levels, its flow rate can increase to over $300 \mathrm{~m}^{3} / \mathrm{s}$. The Reka-Timavo conduit system can be reached in several deep caves on the Slovenian and Italian side, including the caves Jama $1 \mathrm{v}$ Kanjaducah and Labodnica/Abisso di Trebiciano.

The main springs of the area are the Timava/Timavo and Sardoč/Sardos springs. The first has a minimum discharge of $7.4 \mathrm{~m}^{3} / \mathrm{s}$, a maximum of $158 \mathrm{~m}^{3} / \mathrm{s}$ and a mean of $29.3 \mathrm{~m}^{3} / \mathrm{s}$ (Gemiti 1995) and the latter a minimum discharge of $0.6 \mathrm{~m}^{3} / \mathrm{s}$, a maximum of $5.6 \mathrm{~m}^{3} / \mathrm{s}$ and a mean of $1.9 \mathrm{~m}^{3} / \mathrm{s}$ (Gemiti 2004). At the Sardoč/Sardos spring the first water supply system in Italy was constructed in 1922 and at present it supplies about 250,000 inhabitants with drinking water. The third spring in order of discharge magnitude is the Nabežina/Aurisina spring with a mean value of $0.3 \mathrm{~m}^{3} / \mathrm{s}$. Between Timava/Timavo and Nabrežina/Aurisina springs, several small coastal springs arise, their average estimated discharge is 0.5-1 $\mathrm{m}^{3} / \mathrm{s}$ (Gemiti 1984a, 1995; Zini et al. 2014; Cucchi et al. 2015). The springs west of the Sardoč/Sardos spring are not influenced by the waters of the Reka-Timavo aquifer system (Calligaris et al. 2019).

The southern part of the railway route in the karst area is located in the catchment area of the Rižana spring, which was already in use in the early $19^{\text {th }}$ century, while in 1935 a regional water supply system was constructed to supply Slovenia's coastal municipalities with drinking water. Today a majority of the inhabitants of this area $(86,000$ permanent inhabitants, increasing to 120,000 during the tourist season) are connected to this water supply network (Fig. 2). Based on the conducted hydrogeological research and numerous tracer tests (Krivic et al. 1987, 1989) the catchment area of the spring was estimated at $247 \mathrm{~km}^{2}$. Most of it is karstic, however, the spring is also recharged by the sinking rivers at the southern edge of the flysch Brkini Hills. The location of the spring is linked to the contact of the carbonate aquifer with the very poorly permeable 


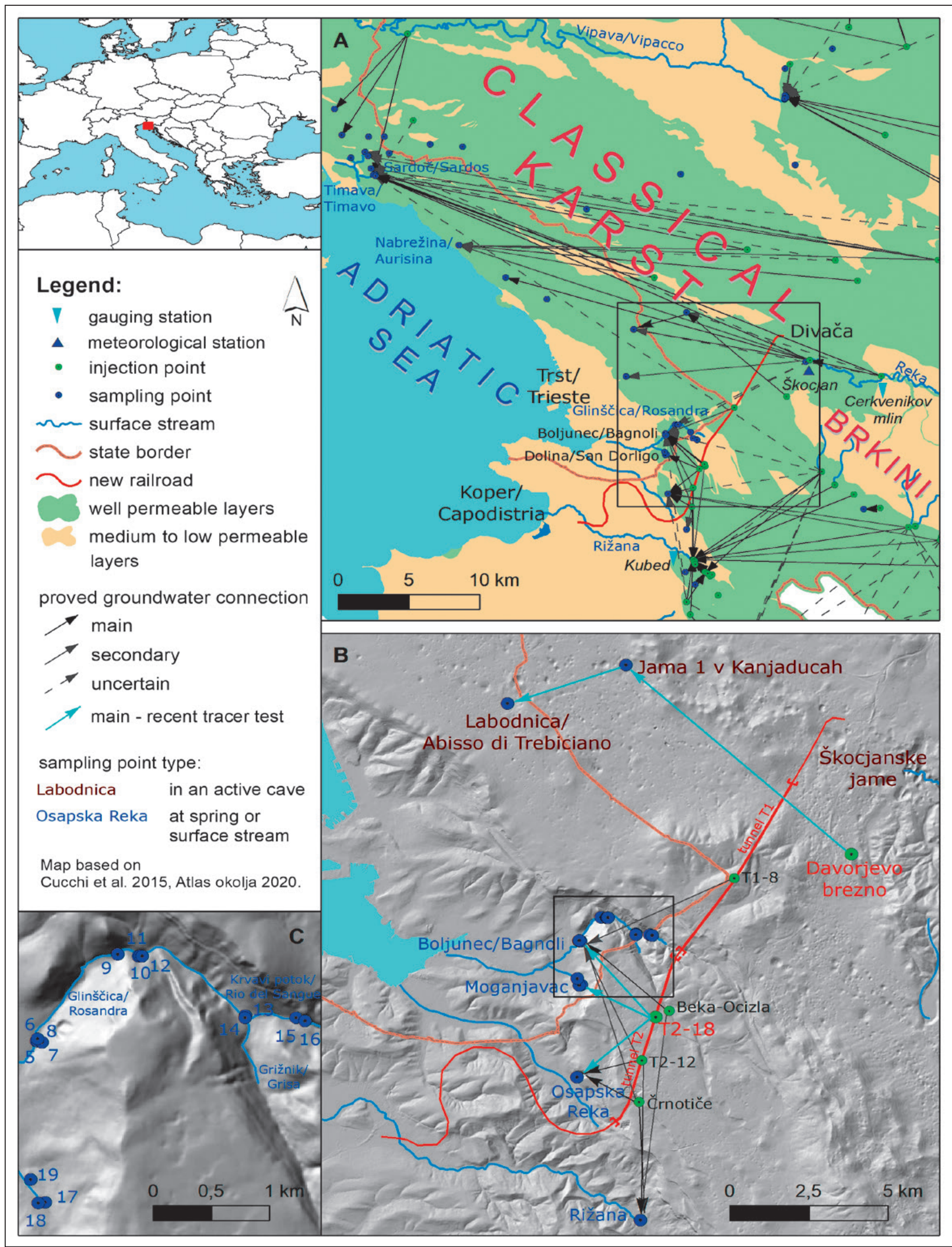

Fig. 1: A) Hydrogeological map of the broader area of the planned route with the results of previous tracer tests; B) map of the recent tracer test results and C) location of sampling points in the Glinščica/Rosandra valley (for names of the springs see Tab. 3). 
flysch rocks, across which the Rižana River flows into the Adriatic Sea. The flow rates of the Rižana River are between $70 \mathrm{~L} / \mathrm{s}$ and $63.2 \mathrm{~m}^{3} / \mathrm{s}$, while the mean flow rate is $3.5 \mathrm{~m}^{3} / \mathrm{s}$ (ARSO 2020).

To the north of Rižana, several smaller springs are located at the contact between flysch and limestone. The intermittent spring of the Osapska Reka can reach the flow rate of several $\mathrm{m}^{3} / \mathrm{s}$ after intense precipitation. It is the overflow of the waters from the catchment area of the Rižana spring in times of high water conditions (Krivic et al. 1989). On the Italian side of the border, in the Glinščica/Rosandra valley at an altitude of around 60 $\mathrm{m}$ a.s.l., in the village of Boljunec/Bagnoli della Rosandra there are several springs known under the common name of Boljunec/Bagnoli (Fig. 1). The springs Na placu/ Abbeveratoio and Pri pralnici/Lavatoio (water supply of a fish farm) are permanent; occasionally, water also flows out of a karst cave Jama/Antro di Bagnoli as an overflow of the Pri pralnici/Lavatoio spring in times of high water conditions (Fig. 3).

More to the north is the Glinščica/Rosandra River watershed. The river originates at the confluence of the Krvavi potok/Rio del Sangue and Grižnik/Grisa torrents and is recharged by several small springs with a discharge

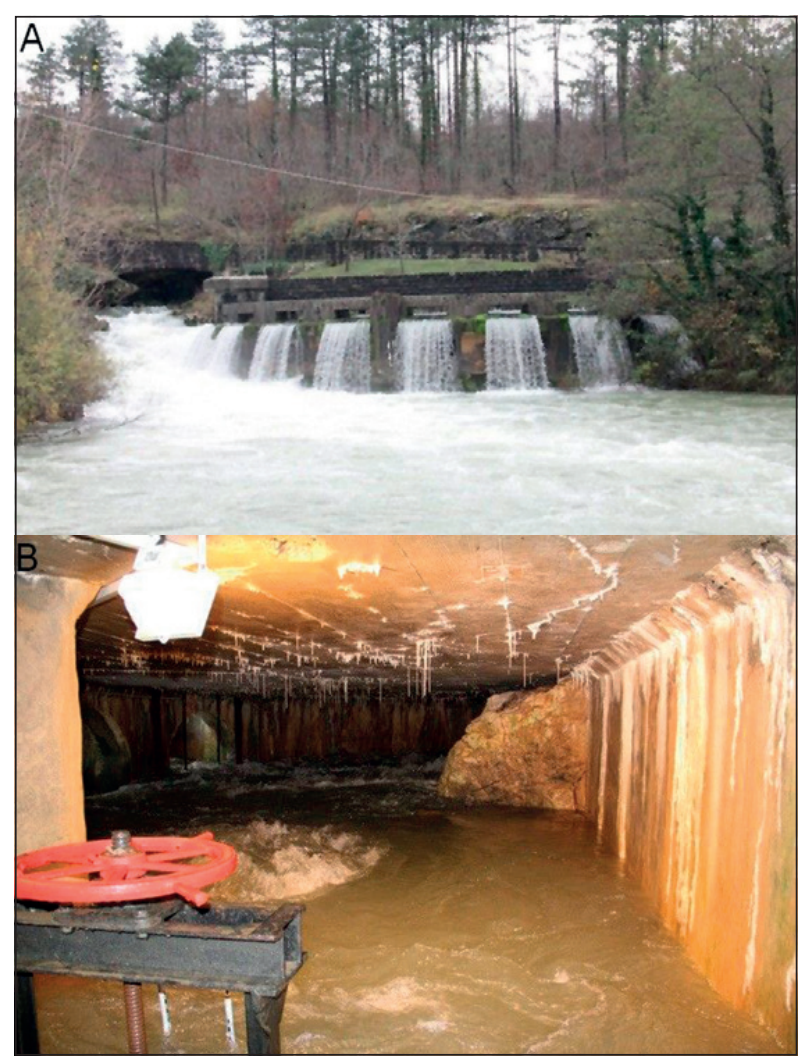

Fig. 2: The Rižana spring is an extremely important source for drinking water supply; A) the overflow of the spring at the reservoir; B) the spring in the reservoir (Photos: J. Kogovšek, M. Petrič). of few L/s. The Zroček 1 and Zroček 2 springs flow into the Krvavi potok/Rio del Sangue, while Klinšca/Oppia 1 and Klinšca/Oppia 2 feed the downstream Glinščica/ Rosandra River (Zini et al. 2011). In the area of Dolina/ San Dorligo village there are three smaller karst springs which used to be or still are used as local water sources (Na Kaluži, Moganjevac, Zgurenc).

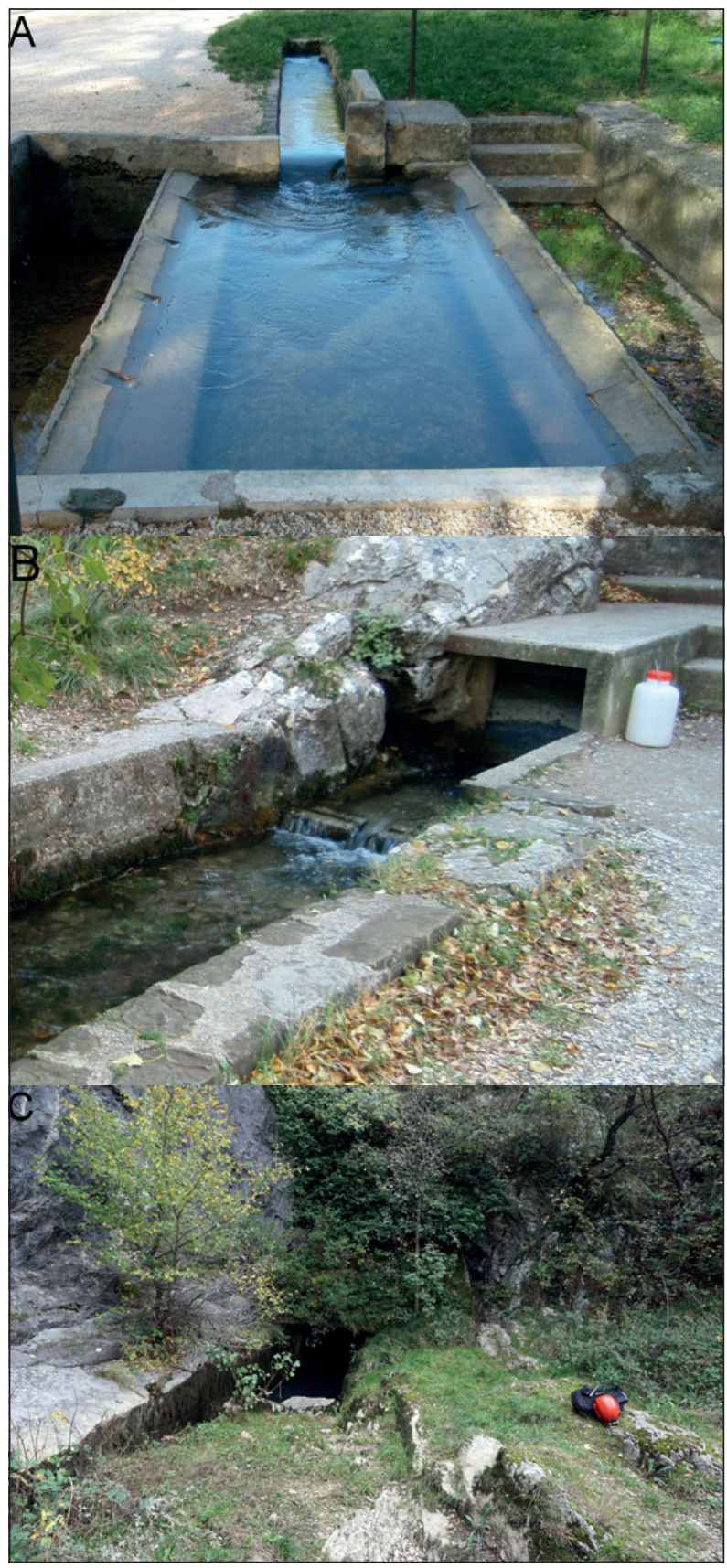

Fig. 3: In the village of Boljunec/Bagnoli della Rosandra, the springs $\mathrm{Na}$ placu/Abbeveratoio (A) and Pri pralnici/Lavatoio (B) are permanent; there is also the intermittent spring of Jama/Antro di Bagnoli (C) (Photos: M. Petrič). 


\section{PREVIOUS TRACER TESTS AND REASONS FOR NEW RESEARCH}

The first tracings were conducted in the Classical Karst already at the beginning of the twentieth century and were followed by many others, which showed the connections of the Reka River from the Škocjanske jame caves to the Timava/Timavo springs and some other smaller springs in the Gulf of Trieste (Timeus 1928; Mosetti 1965; Gemiti 1984b, 1998; Galli 2012; Peric 2012). The tracers were also recovered in various water caves inbetween (e.g., Jama $1 \mathrm{v}$ Kanjaducah, Labodnica/Abisso di Trebiciano; Fig. 1). The determined flow velocities (with regard to duration of the transfer of the tracer and the linear distance between the injection point and the point in which the tracer appeared), which depend on the hydrological conditions, amount from 47 to $204 \mathrm{~m} / \mathrm{h}$ (Turpaud et al. 2018).

Between 1985 and 1987 (Krivic et al. 1987, 1989) numerous tracer tests were conducted in the sinking streams at the foothills of the Brkini Hills with the intention of determining the recharge area of the Rižana spring; certain connections with the Osapska Reka spring were also established. Some indications of groundwater connections between the most western ponors and the springs of Timava/Timavo and Boljunec/Bagnoli were assessed as uncertain.

The tracer tests described above were not enough to determine more precisely the directions and characteristics of the flow of water away from the area of the planned railway route. Therefore, three additional tracer tests were conducted in 2001, 2009 and 2010 with injections into a sinking stream to the Beka-Ocizla Cave system, into a fissure on the surface and into two boreholes (Kogovšek \& Petrič 2004; Petrič \& Kogovšek 2011; Gabrovšek et al. 2015). The results are summed up in Tab. 1.

Summing up the findings of the tracings described in this chapter, it can be said with certainty that the sinking river Reka flows towards the springs in the Gulf of
Trieste, especially towards the Timava/Timavo springs. The tracing conducted in the T1-8 borehole with $0.3 \mathrm{~kg}$ of amidorhodamine $\mathrm{G}$, proved a secondary connection with the springs in Boljunec/Bagnoli, with a highly probable main direction towards the springs in the Gulf of Trieste. Confirming this direction would require the use of a much greater quantity of tracer for the tracing in the T1-8 borehole due to the great distance and higher flow rates of the Timava/Timavo spring; however, that was impossible under the given conditions because of the proximity of the Boljunec/Bagnoli spring and the danger of colouring it with too high concentrations of the tracer.

Several tracings were conducted in the area of the T2 tunnel; in the northern part, the main direction of the underground flow towards the Boljunec/Bagnoli springs has been confirmed, and in the southern part the direction towards the Rižana and Osapska Reka springs has been confirmed. The watershed between them could not be delineated more precisely without conducting an additional tracing in the intermediate area.

That is why in the final phase of the research, before beginning the construction of the new railway line, it was decided that another multi-tracer test should be conducted to further explain the directions and characteristics of the underground flow in both above-mentioned sections of the line. Because a great part of the railway route is running through the tunnels, injection points bypassing vadose zone have been selected in order to assess similar flow conditions to possible contamination from construction or operation of tunnels. In the area of the T1 tunnel the karst cave Davorjevo brezno was chosen (Fig. 1). The location of the cave is roughly $3 \mathrm{~km}$ east of the tunnel, between the Škocjanske jame caves and the T1-8 borehole, which were already used as injection points in previous tracings. In order to avoid the need to use a greater quantity of the tracer to confirm the connection to the Timava/Timavo springs, the Jama $1 \mathrm{v}$ Kaniaducah

Tab. 1: Results of tracer tests in 2001, 2009 and 2010. For location of injection points see Fig. $1 B$.

\begin{tabular}{|l|c|c|c|c|c|}
\hline Injection point & Date of injection & Tracer & Sampling point & $\begin{array}{c}\text { Proved } \\
\text { connection }\end{array}$ & $\begin{array}{c}\text { Peak velocity } \\
\text { [m/h] (Recovery) }\end{array}$ \\
\hline $\begin{array}{l}\text { Beka-Ocizla } \\
\text { Cave system }\end{array}$ & $29 / 3 / 2001$ & uranine & $\begin{array}{c}\text { Pri pralnici/Lavatoio } \\
\text { Jama/Antro di B. } \\
\text { Rižana }\end{array}$ & $\begin{array}{c}\text { main } \\
\text { main } \\
\text { secondary }\end{array}$ & $\begin{array}{c}33 \\
29(91 \% *) \\
6(2 \%)\end{array}$ \\
\hline $\begin{array}{l}\text { Črnotiče } \\
\text { (fissure) }\end{array}$ & $1 / 12 / 2009$ & uranine & $\begin{array}{c}\text { Rižana } \\
\text { Osapska Reka } \\
\text { Pri pralnici/Lavatoio }\end{array}$ & $\begin{array}{c}\text { main } \\
\text { main } \\
\text { secondary }\end{array}$ & $\begin{array}{c}22(87 \%) \\
33(11 \%) \\
10(1 \%)\end{array}$ \\
\hline $\begin{array}{l}\text { Borehole } \\
\text { T2-12 }\end{array}$ & $18 / 11 / 2010$ & uranine & $\begin{array}{c}\text { Rižana } \\
\text { Osapska Reka }\end{array}$ & $\begin{array}{c}\text { main } \\
\text { main } \\
\text { secondary }\end{array}$ & $\begin{array}{c}62(41 \%) \\
23(33 \%) \\
48(2 \%)\end{array}$ \\
\hline $\begin{array}{l}\text { Borehole } \\
\text { T1-8 }\end{array}$ & $18 / 11 / 2010$ & amidorhodamine G & Pri pralnici/Lavatoio & secondary & $61(7 \%)$ \\
\hline
\end{tabular}

* Sum of recovered tracer through the Pri pralnici/Lavatoio and Jama/Antro di Bagnoli springs. 
and Labodnica/Abisso di Trebiciano caves in the RekaTimavo karst aquifer were chosen as sampling points.

The T2-18 borehole was chosen as the injection point in the area of the T2 tunnel; the borehole was drilled in a zone with the least reliable prediction of the underground flow direction based on the existing results, i.e., the possible direction towards all three main springs in the area (Rižana, Osapska Reka, Boljunec/Bagnoli).

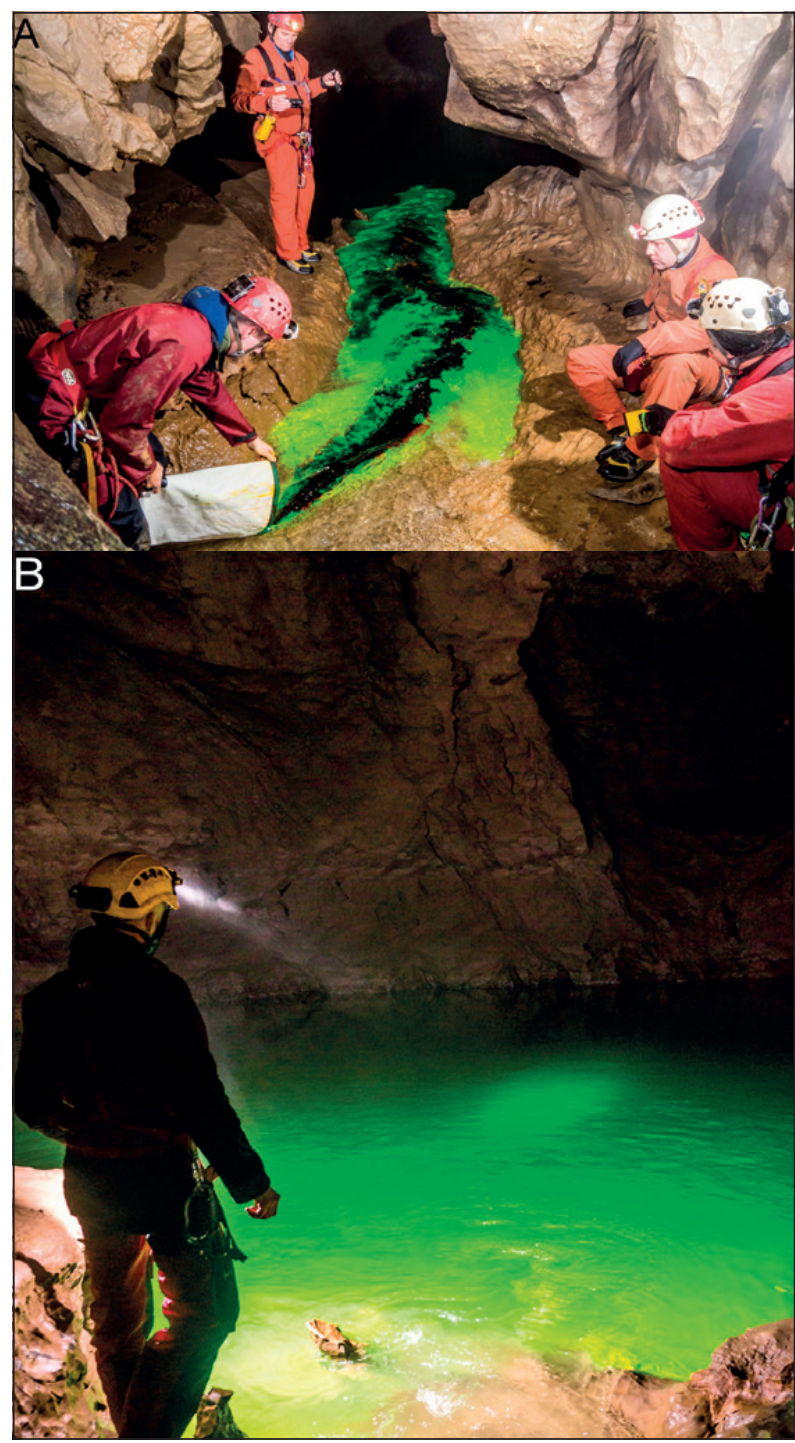

Fig. 4: Injecting $3 \mathrm{~kg}$ of uranine on 27 November 2018 at 12:05 into the stream (A) upstream of the terminal siphon (B) in Davorjevo brezno (Photos: M. Blatnik).

\section{METHODS}

Daily precipitation data (ARSO 2019) and flow rates of the sinking river Reka at the hydrological station Cerkvenikov mlin and of the Rižana River at the hydrological station Kubed in 30-minute intervals (ARSO 2020) were obtained from ARSO websites. At the Boljunec/Bagnoli Spring water levels have been monitored since 2010 in 30-minute intervals with the Onset HOBO (U20) programmable autonomous instruments; occasionally, the total flow rate of the joint stream was also measured with the current meter Ott HydroMet C20 or SonTek FlowTracker 2. Additionally, the flow rate of the Na placu/Abbeveratoio spring was measured separately, as according to previous research (Gabrovšek et al. 2015), it has a different recharge area than the springs Pri pralnici/Lavatoio and Jama/Antro di Bagnoli. Based on these measurements, the total flow rate of the springs Pri pralnici/Lavatoio and Jama/Antro di Bagnoli was determined as the difference between the measured values. By comparing the measured flow rates to the simultaneously measured water levels in Jama/Antro di Bagnoli, the rating curve of dependence between the water levels and flow rates was obtained, and based on the equations obtained the flow rates were calculated for all the measured levels. Unpublished data from periodic measurements of flow rates in Jama $1 \mathrm{v}$ Kanjaducah using the salt dilution method were provided by colleagues from the Karst Research Institute ZRC SAZU. A comparison with the flow rates data for the Reka River showed very similar values, with a delay of approximately 12 hours.

Davorjevo brezno is a $303 \mathrm{~m}$ deep and just over 5 $\mathrm{km}$ long karst cave with an entrance at the altitude of 510 $\mathrm{m}$ a.s.l. (Mesarec 2011); the injection point is located 279 $\mathrm{m}$ deeper in the terminal siphon at the altitude of $231 \mathrm{~m}$ a.s.l. (Tab. 2). The flow rate of the stream upstream of the siphon was measured first, using the salt dilution method. At a flow rate of $53 \mathrm{~L} / \mathrm{s}$, a solution of $3 \mathrm{~kg}$ of uranine was poured into it on 27 November 2018 at 12:05 (Fig. 4).

The T2-18 borehole in the area of the T2 tunnel was chosen as the second injection point (Fig. 1; Tab. 2). While drilling, zones of greater fissuration and good water permeability were detected in the borehole in the limestone of Eocene age, which guarantees a relatively fast underground outflow of the injected tracer. In the borehole with a well top at the height of $408 \mathrm{~m}$, levels of groundwater were measured at altitudes between 249

Tab. 2: Coordinates of injection points (in Davorjevo brezno $Z$ is the altitude of the terminal siphon, while in the borehole it is the highest measured water level) and the amounts of the tracers used.

\begin{tabular}{|l|c|c|c|c|c|}
\hline Injection point & GKX & GKY & Z (m a.s.I.) & Tracer & Amount of tracer \\
\hline Davorjevo brezno & 419990 & 55609 & 231 & uranine & $3 \mathrm{~kg}$ \\
\hline Borehole T2-18 & 413818 & 50096 & 254 & naphthionate & $3 \mathrm{~kg}$ \\
\hline
\end{tabular}




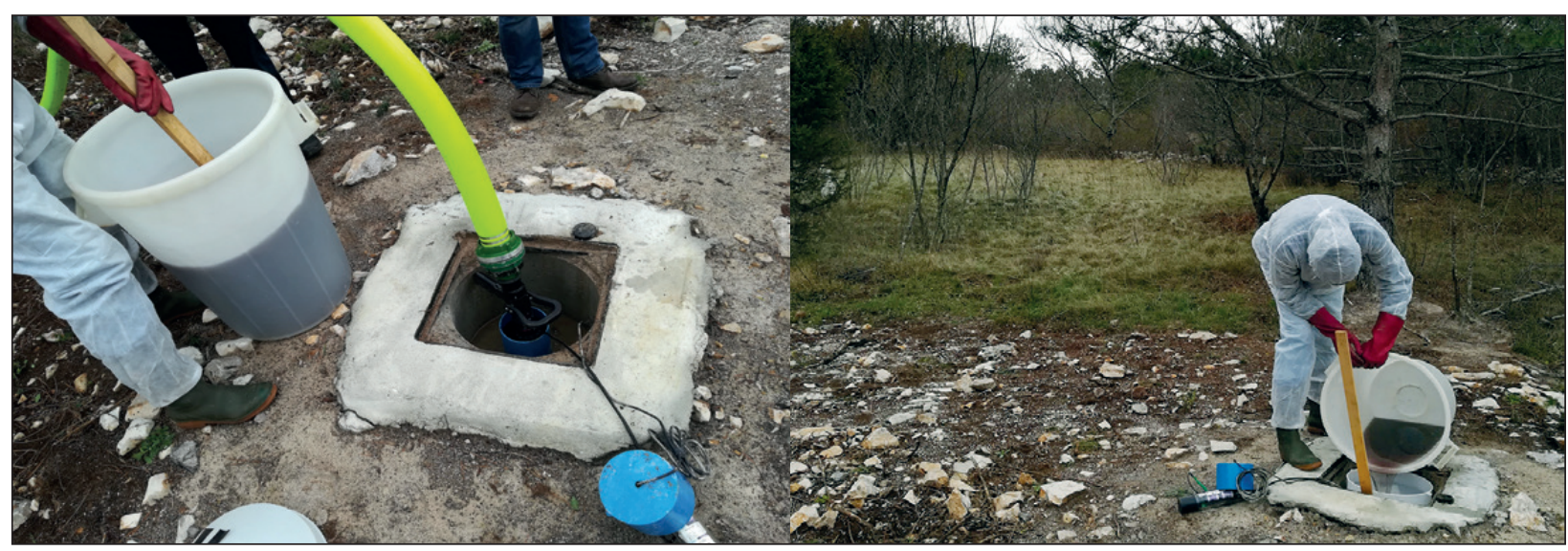

Fig. 5: A solution of $3 \mathrm{~kg}$ of naphthionate was injected into the T2-18 borehole on 27 November 2018 at 12:15 (Photos: M. Cuk).

and $254 \mathrm{~m}$ a.s.l. A solution of $3 \mathrm{~kg}$ of naphthionate was poured into the borehole on 27 November 2018 at 12:20 (Fig. 5) and washed away with $5.5 \mathrm{~m}^{3}$ of water from a tank.

Based on the known hydrogeological characteristics, a total of 19 points were chosen for the sampling, namely 13 springs, 2 cave streams and 4 surface streams. Several blank samples were collected beforehand at all the points (Tab. 3) in October and November 2018.

As the connection between Jama $1 \mathrm{v}$ Kanjaducah, Labodnica/Abisso di Trebiciano and Timava/Timavo springs is well known (Boegan 1938; Cucchi et al. 2015; Calligaris et al. 2018; Calligaris et al. 2019), it was de- cided not to sample the Timava/Timavo springs, but only the waters flowing in the two caves. In this way it was possible to use a smaller amount of tracer. In the two caves, the samples were collected manually. Between 30 November and 20 December 2018, 11 samples were taken in the cave Jama $1 \mathrm{v}$ Kanjaducah; with initially a daily frequency, and later on every two days. Between 27 November and 21 December 2018, 18 samples were taken in the Labodnica/Abisso di Trebiciano cave. Until 9 December 2018, the sampling was conducted once a day, and after that every two days. In this cave, for uranine detection also a field fluorimeter (GGUN-FL24 fluorimeter), having a sampling rate of 15 minutes, was installed. Due

Tab. 3: Coordinates of sampling points (CS-cave stream, SP-spring, SS-surface stream) and linear distances between the two injection points (L1 for Davorjevo brezno and L2 for the T2-18 borehole) and the sampling points.

\begin{tabular}{|l|l|c|c|c|c|c|c|}
\hline No. & Sampling points & Type & GKY & GKX & Z (m) & L $1(\mathrm{~km})$ & $\mathrm{L} 2(\mathrm{~km})$ \\
\hline 1 & Jama 1 v Kanjaducah & CS & 412875 & 62010 & 15 & 9.9 & 12.0 \\
\hline 2 & Labodnica/Abisso di Trebiciano & CS & 409140 & 60708 & 12 & 12.3 & 11.6 \\
\hline 3 & Rižana & SP & 413334 & 43215 & 69 & 13.9 & 6.9 \\
\hline 4 & Osapska Reka & SP & 411330 & 48050 & 105 & 11.5 & 3.1 \\
\hline 5 & Boljunec/Bagnoli (joint) & SP & 411392 & 52671 & 60 & 9.2 & 3.5 \\
\hline 6 & Pri pralnici/Lavatoio & SP & 411407 & 52668 & 61 & 9.2 & 3.5 \\
\hline 7 & Jama/Antro di Bagnoli & SP & 411442 & 52657 & 62 & 9.2 & 3.5 \\
\hline 8 & Na placu/Abbeveratoio & SP & 411404 & 52689 & 62 & 9.2 & 3.5 \\
\hline 9 & Glinščica/Rosandra & SS & 412094 & 53470 & 89 & 8.3 & 3.8 \\
\hline 10 & Klinšca/Oppia 1 & SP & 412271 & 53455 & 92 & 8.0 & 3.7 \\
\hline 11 & Klinšca/Oppia 2 & SP & 412287 & 53458 & 93 & 8.0 & 3.7 \\
\hline 12 & Glinščica/Rosandra (above Oppia) & SS & 412306 & 53454 & 94 & 8.0 & 3.7 \\
\hline 13 & Krvavi potok/Rio del Sangue & SS & 413192 & 52903 & 178 & 7.8 & 2.9 \\
\hline 14 & Grižnik/Grisa & SS & 413191 & 52883 & 178 & 7.8 & 2.9 \\
\hline 15 & Zroček 1 & SP & 413633 & 52883 & 250 & 7.2 & 2.3 \\
\hline 16 & Zroček 2 & SP & 413706 & 52854 & 241 & 7.4 & 2.4 \\
\hline 17 & Moganjavec & SP & 411470 & 51179 & 142 & 9.7 & 2.6 \\
\hline 18 & Zgurenc & SP & 411409 & 51171 & 145 & 9.7 & 2.6 \\
\hline 19 & Na Kaluži & SP & 411345 & 51391 & 103 & 9.7 & 2.8 \\
\hline
\end{tabular}


to some instrumental problems, it has only been possible to recover the data from 13 December to 21 December 2018.

The ISCO 6712 automatic samplers were installed on 26 November 2018 at the Rižana (Fig. 6) and Osapska Reka springs, and at the joint stream of the Boljunec/ Bagnoli springs. The sampling frequency ranged from every 6 hours at the beginning of the test to twice a day when the sampling was completed on 13 February 2019. For the detection of uranine, continuous fluorescence measurements were carried out in parallel at the Rižana spring in 30-minute intervals from 27 November 2018 to 28 January 2019 using the Götschy Optotechnik LLF-M field fluorometer.

Between 26 November 2018 and 20 December 2018, periodic manual sampling was conducted (once a day or every two days, depending on the precipitation conditions) at seven springs (Na placu/Abbeveratoio, Pri pralnici/Lavatoio, Jama/Antro di Bagnoli, Klinšca/Oppia 1 and 2, Zroček 1 and 2) and at five sections of the surface streams in the Glinščica/Rosandra valley and of three springs in the area of Dolina/San Dorligo village (Na Kaluži, Moganjevac, Zgurenc).

All collected samples were properly stored at $\sim 4^{\circ} \mathrm{C}$ in dark vials. In order to establish the presence of tracers, they were analysed in the laboratory of the Karst Research Institute ZRC SAZU with the PERKIN ELMER LS 45 luminescence spectrometer; the uranine at $\mathrm{E}_{\mathrm{ex}}=491 \mathrm{~nm}, \mathrm{E}_{\mathrm{em}}=512 \mathrm{~nm}$ and the naphthionate at $\mathrm{E}_{\mathrm{ex}}=320 \mathrm{~nm}, \mathrm{E}_{\mathrm{em}}=430 \mathrm{~nm}$ (Käss 1998, Meus et al. 2006). Analyses were conducted soon after the sampling. After decantation, the entire batch of samples was analysed again as the sampling was completed at individual sampling points. This was necessary because high turbidity levels were detected in most of the samples taken from the springs, especially after intense precipitation, which interfered with the fluorescence measurements. Due to the poorer stability of the naphthionate (Goldscheider et al. 2001, Benischke et al. 2007) the samples were analysed for the presence of this tracer within 14 days. According to the literature (Benischke et al. 2007) the instrumental detection limit for uranine is $0.001 \mu \mathrm{g} / \mathrm{L}$. The naphthionate has less favourable properties, especially in waters containing organic contamination; thus, the literature mentions diverse detection limits, ranging from 0.1 to $1 \mu \mathrm{g} / \mathrm{L}$; the appearance of higher values is not excluded (Meus et al. 2014).

With luminescence spectrometer LS45 measured concentrations of uranine in 5 samples taken manually in Labodnica/Abisso di Trebiciano from 13 December to 21 December 2018, were used for calibration of field fluorimeter GGUN-FL24. For the calibration of LS45 and LLF-M, samples of different concentrations were prepared with the used uranine and water from the Rižana spring before the injection.

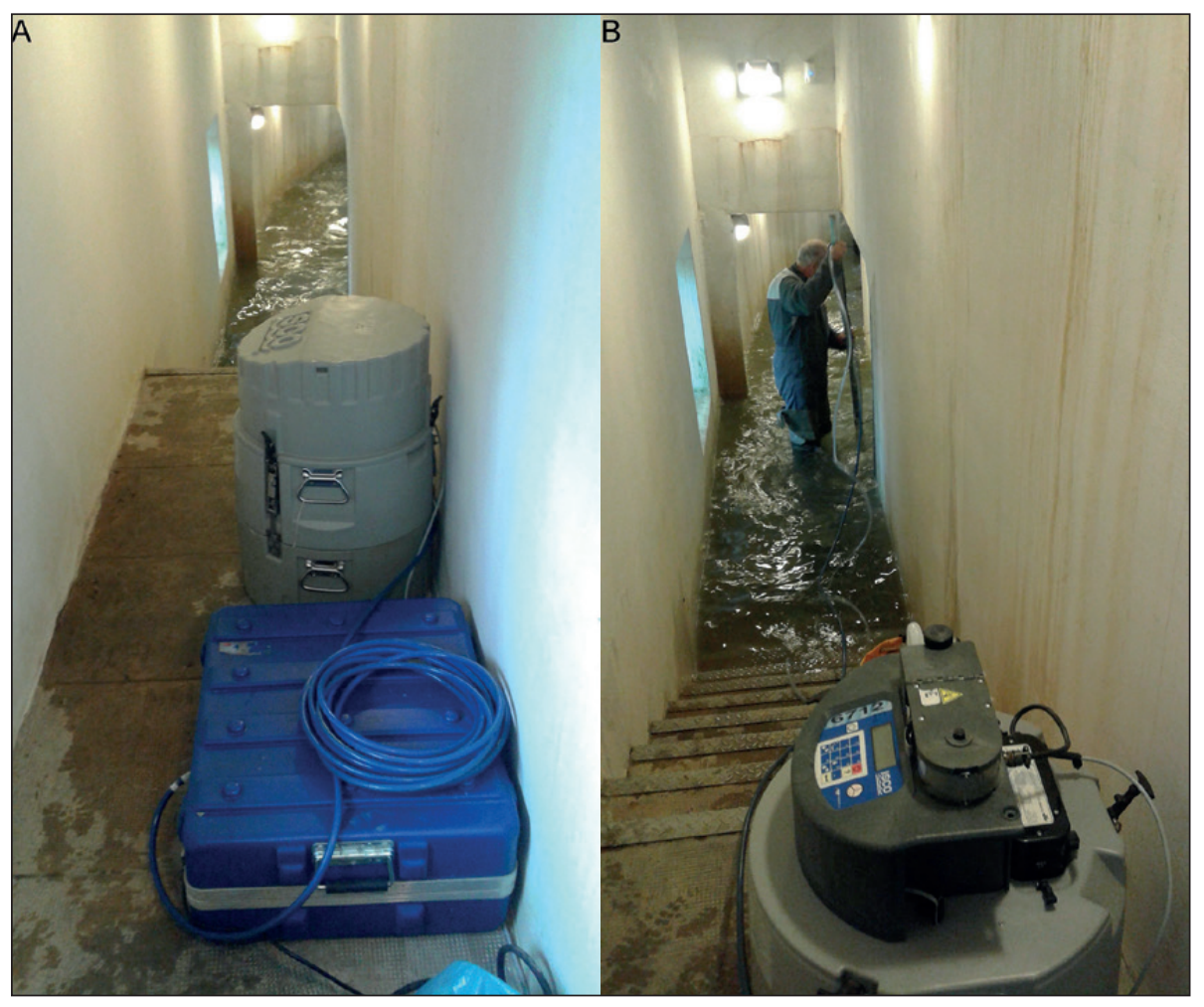

Fig. 6: The sampling point at the Rižana spring; A) The ISCO 6712 automatic water sampler and the LLF-M field fluorometer; B) the setting up of probes and pumping pipes (Photos: M. Petrič). 


\section{RESULTS AND DISCUSSION}

\section{PRECIPITATION AND HYDROLOGICAL CONDITIONS}

To illustrate the precipitation and hydrological conditions in the period prior to and during the testing, the results are summarized in Fig. 7, where the data for the period between 20 October 2018 and 14 February 2019 are presented.

After abundant rainfall in late October 2018, the flow rates of the Reka and Rižana rivers were high (more than $229 \mathrm{~m}^{3} / \mathrm{s}$ for Reka and $35 \mathrm{~m}^{3} / \mathrm{s}$ for Rižana); in early November the water level slowly began to drop. Then on 25 and 26 November 2018 a new rainfall event of $34 \mathrm{~mm}$ slightly increased the flow rates again. The tracers were injected on 27 November 2018. This was followed by a few minor precipitation events in early December and by heavier rainfall on 8 December 2018 with $42 \mathrm{~mm}$ of precipitation. Even after the first tracer breakthrough curve, the sampling was continued until February 2019, when very high flow rates were reached after several days of precipitation (more than $300 \mathrm{~m}^{3} / \mathrm{s}$ for Reka and $68 \mathrm{~m}^{3} / \mathrm{s}$ for Rižana).

\section{TRACING WITH URANINE \\ (injection into Davorjevo brezno)}

Uranine was detected for the first time in a sample taken in the cave Jama $1 \mathrm{v}$ Kanjaducah on 8 December 2018 at 20:00 (Fig. 8). Since the concentration was very low $(0.012 \mu \mathrm{g} / \mathrm{L})$, it can be deduced that this sample shows the beginning of tracer appearance. The peak of the tracer breakthrough curve can be determined less reliably, because in that period the sampling was conducted every 2 days. The highest concentration of $0.56 \mu \mathrm{g} / \mathrm{L}$ was measured in a sample taken on 11 December 2018 at 14:40. As expected, the tracer also appeared, with a shorter delay, in the Labodnica/Abisso di Trebiciano cave; the first appearance $(0.022 \mu \mathrm{g} / \mathrm{L})$ was detected on 9 December 2018 at $12: 40$, while the highest concentration of $0.58 \mu \mathrm{g} / \mathrm{L}$ was measured in the sample taken on 13 December 2018 at 12:00. The decrease of tracer concentrations was measured also by the field fluorimeter (Fig. 8).

Taking into account the linear distance between the injection point and Jama $1 \mathrm{v}$ Kanjaducah (Tab. 4) and the time interval from injection to the first tracer appearance, the maximum flow velocity of $37 \mathrm{~m} / \mathrm{h}$ was calculated; by taking into account the time interval from injection to the appearance of the highest tracer concentration, the peak velocity of $29 \mathrm{~m} / \mathrm{h}$ was calculated (Tab. 3).

A temporally displaced flow rates curve for the Reka River was used to assess the flow rates in the cave Jama $1 \mathrm{v}$ Kanjaducah and, based on this, the proportion of recovered tracer was calculated (Fig. 8). Due to such approximate method of determining the flow rate and the small sampling frequency it is only a rough estimate, but it nevertheless enabled an evaluation of the tracing results. In the first flood pulse after injection, about three-
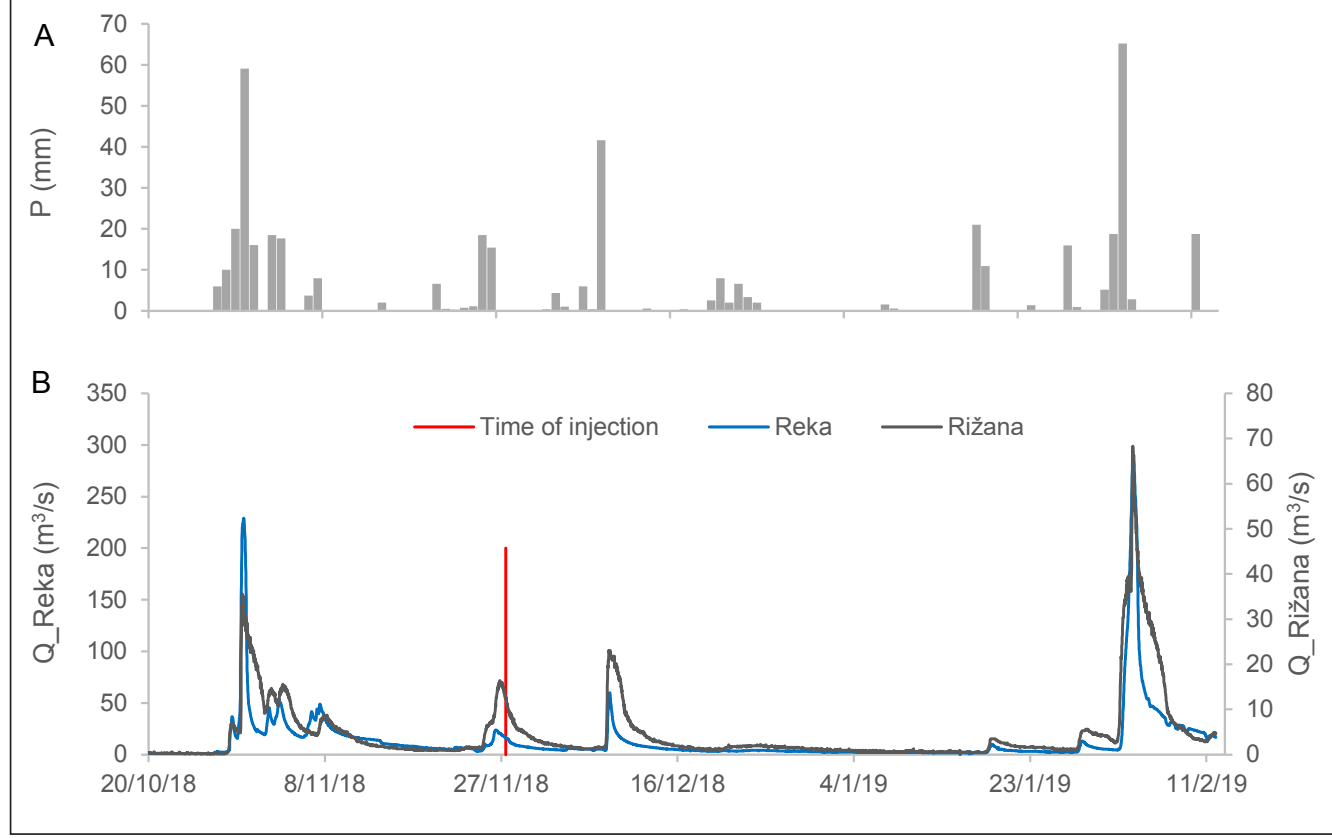

Fig. 7: A) Daily precipitation $(P)$ at the ARSO Škocjan station; B) the flow rates (Q) of the Rižana River at the ARSO Kubed station and of the Reka River at the ARSO Cerkvenikov mlin station, measured at 30-minute intervals for the period prior to injection and throughout the sampling. 


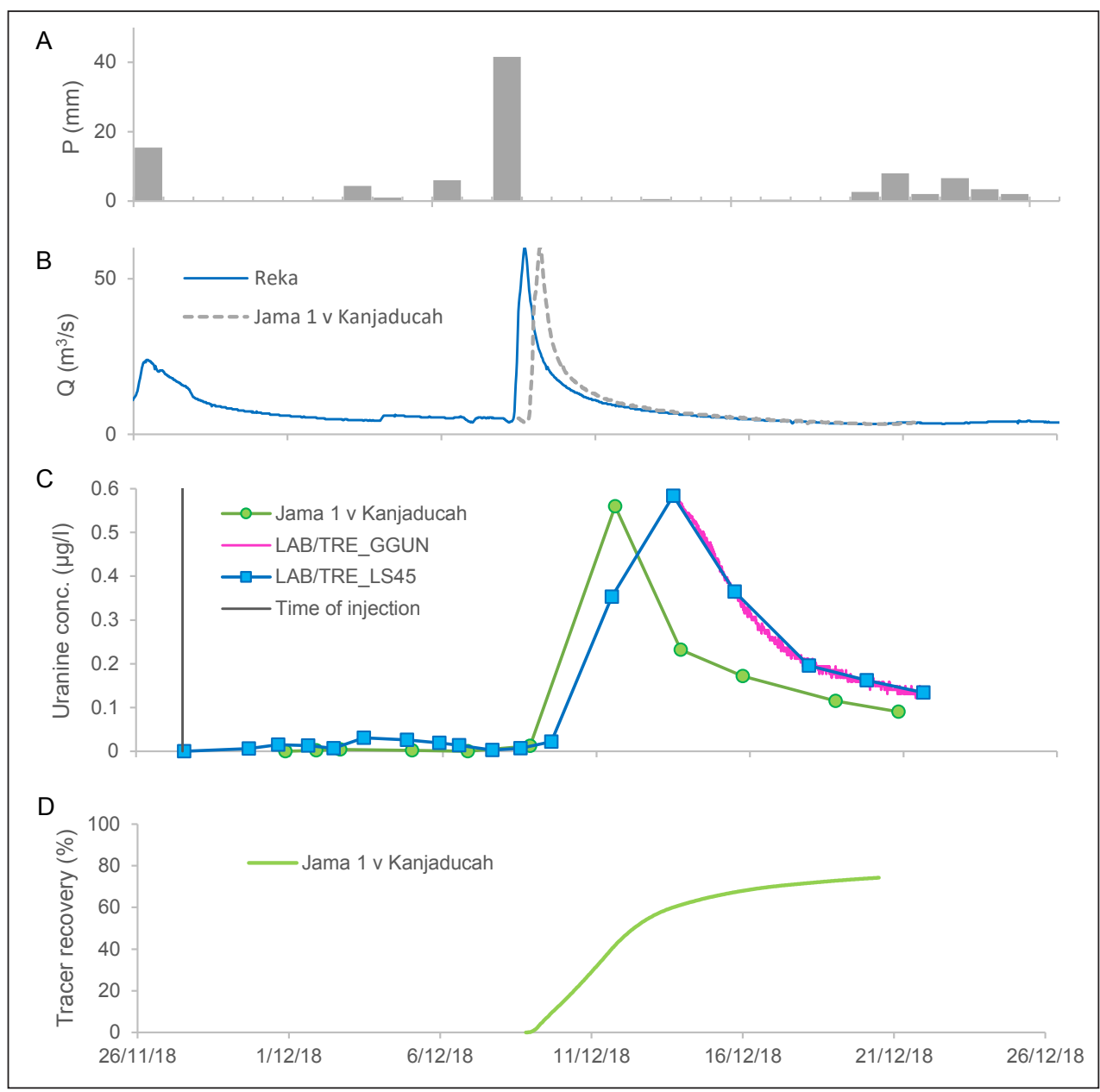

Fig. 8: A) Precipitation (P) at the ARSO Škocjan station; B) the measured flow rates $(Q)$ of the Reka River at the ARSO Cerkvenikov mlin station and the estimated flow rates (Q) of the Reka River in Jama 1 $v$ Kanjaducah; C) uranine concentrations in samples from Jama $1 v$ Kanjaducah and Labodnica/Abisso di Trebiciano (LAB/TRE_ GGUN: measured with field fluorimeter; LAB/ TRE_LS45: measured in samples in laboratory); D) the estimated share of recovered tracer in Jama $1 \mathrm{v}$ Kanjaducah.

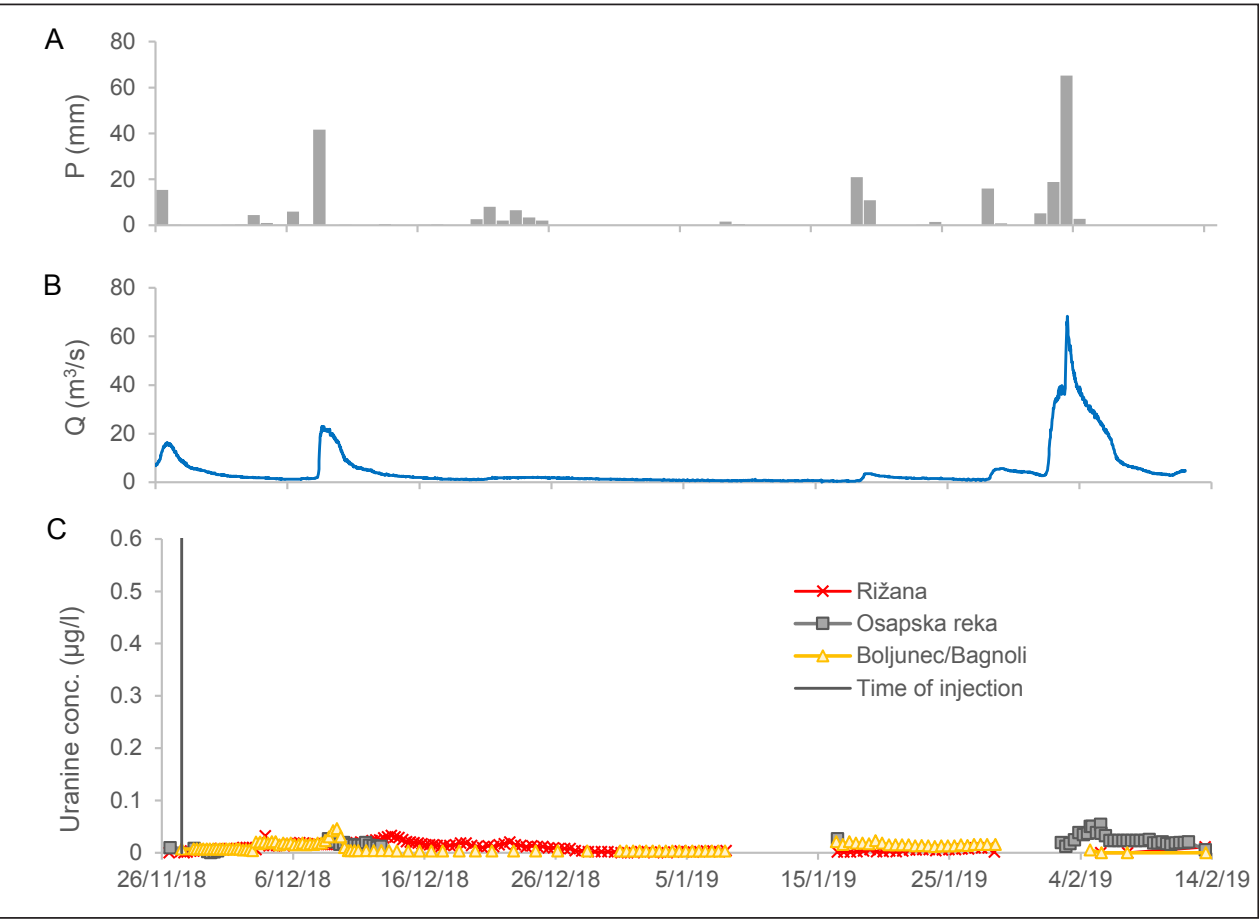

Fig. 9: A) Precipitation (P) at the ARSO Škocjan station; B) the measured flow rates (Q) of the Rižana River at the ARSO Kubed station; C) the measured uranine concentrations in Rižana, Osapska Reka and Boljunec/Bagnoli. 
quarters of the injected uranine passed through Jama $1 \mathrm{v}$ Kanjaducah. It can be deduced that this is the main flow direction from Davorjevo brezno along a system of interconnected and highly permeable karst fissures and conduits. Owing to the high proportion of recovered tracer and the demanding fieldwork in the deep karst caves, the sampling was terminated after the first flood pulse had passed through. Based on experience from previous tracings, it can be assumed that the tracer would continue to appear in both caves in smaller concentrations in the subsequent flood pulses, thus further increasing the proportion of the recovered tracer.

The linear distance between the injection point in the Davorjevo brezno cave and the Labodnica/Abisso di Trebiciano cave is $12.3 \mathrm{~km}$ (Tab. 3); taking this distance into account, the maximum and peak flow velocities of $43 \mathrm{~m} / \mathrm{h}$ and $32 \mathrm{~m} / \mathrm{h}$, respectively, were calculated (Tab. 4). However, judging by the characteristics of the RekaTimavo aquifer system proved by other tracer tests, the tracer previously detected in Jama $1 \mathrm{v}$ Kanjaducah also appeared in Labodnica/Abisso di Trebiciano. It therefore travelled from Davorjevo brezno to the conduits of the Reka-Timavo system somewhere between the Škocjanske jame caves and the Jama $1 \mathrm{v}$ Kanjaducah cave, and then through the latter cave towards the Labodnica/ Abisso di Trebiciano cave and finally towards the springs in the Gulf of Trieste. Taking this path into account, the maximum and peak velocities are $48 \mathrm{~m} / \mathrm{h}$ and $36 \mathrm{~m} / \mathrm{h}$, respectively; while the peak velocity between Jama 1 v Kanjaducah and Labodnica/Abisso di Trebiciano is estimated at $88 \mathrm{~m} / \mathrm{h}$. However, the flow velocities are strongly dependent on the rainfall regime which, in turn, influence the hydraulic gradient. Its increase consequently results in an increase of flow velocities. The velocities by tracer tests represent the conditions at the time of the test and higher velocities can be expected. In addition, changes in flow directions due to changes in hydrological conditions are possible. All this should be taken into account when assessing the vulnerability of the springs used for water supply.

In the initial period of the tracer test, before the first tracer appearance, the samples were analysed as soon as they were delivered to the laboratory; the first increase in the measured fluorescence was detected in the joint stream of the Boljunec/Bagnoli springs on 7 December, and the highest value of $0.36 \mu \mathrm{g} / \mathrm{L}$ on 9 December 2018 . Soon afterwards, the increases in fluorescence were also detected in the samples from Jama $1 \mathrm{v}$ Kanjaducah and Labodnica/Abisso di Trebiciano. The analyses conducted after decantation confirmed the uranine concentrations that had originally been measured in both caves; the signal measured later on in the samples from Boljunec/ Bagnoli was much smaller and the measured concentrations were up to $0.046 \mu \mathrm{g} / \mathrm{L}$ (Fig. 9). On the basis of these results the flow of water from Davorjevo brezno towards the springs in Boljunec/Bagnoli cannot be reliably confirmed. Very similar concentrations were measured in the Pri pralnici/Lavatoio and Jama/Antro di Bagnoli springs, and even lower in the Na placu/Abbeveratoio. However, based on these results no definite conclusions on different recharge areas of individual springs in Boljunec/Bagnoli can be made.

Until 14 February 2019, the Rižana and Osapska Reka springs were also sampled (Fig. 9). It has been deduced from the measured fluorescence values that the groundwater from Davorjevo brezno do not flow towards these two springs.

In the samples of the surface stream of the Glinščica/ Rosandra River and its tributaries, increased fluorescence values were measured after the precipitation on 8 December 2018. Considering that the water was very turbid at the time and the increase was detected in one sample only, it was concluded that the increased fluorescence was not the result of uranine coming from Davorjevo brezno, but was induced by increased turbidity.

\section{TRACING WITH NAPHTHIONATE \\ (Injection into the T2-18 Borehole)}

For the area of the T2-18 borehole the possibility of an underground flow towards the springs in Boljunec/Bagnoli and towards the Rižana and Osapska Reka springs was predicted. Confirming this connection with the Rižana spring would require the use of a greater tracer quantity due to the higher flow rates and greater distance; however, that would mean that the nearby springs at Boljunec/Bagnoli, which have a much lower

Tab. 4: Uranine appearance; $L$ - linear distance between injection point and sampling point; $t_{1}$ - time interval from injection to the first tracer detection; $v_{\max }$ - maximum flow velocity; $c_{\max }$ - highest measured tracer concentration; $t_{p}$ - time interval from injection to recording the highest tracer concentration; $v_{p}$ - peak velocity; $R$ - estimated proportion of recovered tracer.

\begin{tabular}{|l|c|c|c|c|c|c|c|}
\hline Uranine & $\mathrm{L}(\mathrm{km})$ & $\mathrm{t}_{1}(\mathrm{~h})$ & $\mathrm{v}_{\max }(\mathrm{m} / \mathrm{h})$ & $\mathrm{c}_{\max }\left(\mathrm{mg} / \mathrm{m}^{3}\right)$ & $\mathrm{t}_{\mathrm{p}}(\mathrm{h})$ & $\mathrm{v}_{\mathrm{p}}(\mathrm{m} / \mathrm{h})$ & $\mathrm{R}(\%)$ \\
\hline Jama 1 v Kanjaducah (KAN) & 9.9 & 272 & 37 & 0.56 & 338 & 29 & 74 \\
\hline Labodnica/Abisso di Trebiciano (LAB/TRE) & 12.3 & 288 & 43 & 0.58 & 384 & 32 & \\
\hline LAB/TRE (through KAN) & 13.9 & 288 & 48 & 0.58 & 384 & 36 & \\
\hline Between KAN and LAB/TRE & 4.0 & & & & 45 & 88 & \\
\hline
\end{tabular}


flow rate, might be dyed visible. For this reason, the fluorescent tracer naphthionate was chosen, which is invisible to the naked eye even in the concentration of $1 \mathrm{~g} / \mathrm{L}$ (Benischke et al. 2007). However, this tracer has a few unfavourable properties that hinder the interpretation of the results of analyses. The natural background values may be increased by the appearance of organic contamination alone, as has been demonstrated by the analysis of blank samples taken during high water con- ditions. Regardless, when conducting the sampling after injection, the concentrations measured in the springs of Boljunec/Bagnoli (up to $6.9 \mu \mathrm{g} / \mathrm{L}$ ) and Osapska Reka (up to $3.5 \mu \mathrm{g} / \mathrm{L}$ ) at the time of a smaller flood pulse in early December 2018 deviate (Fig. 10) and indicate an underground water connection between the T2-18 borehole and both springs Due to the problem with the background values, only a rough assessment of the tracer recovery was possible. It was estimated that approxi-
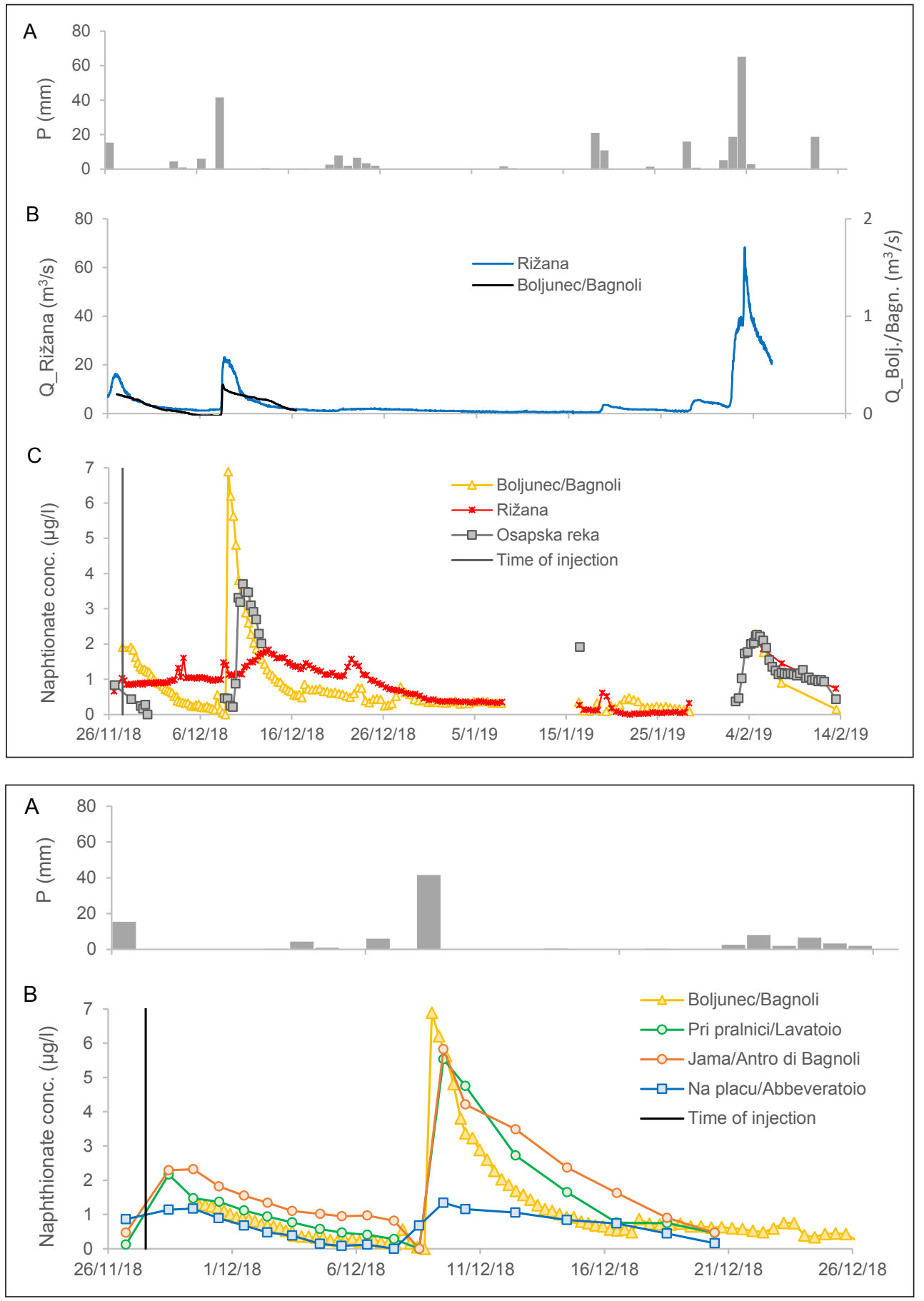

Fig. 10: A) Precipitation (P) at the ARSO Škocjan station; B) the measured flow rates $(Q)$ of the Rižana River at the ARSO Kubed station and the flow rates (Q) of the Boljunec/Bagnoli spring; $C)$ the measured naphthionate concentrations in Rižana, Osapska Reka and Boljunec/Bagnoli.
Fig. 11: A) Precipitation (P) at the ARSO Škocjan station; $B)$ the measured naphthionate concentrations of samples from the individual springs and joint stream in the Boljunec/Bagnoli village. 


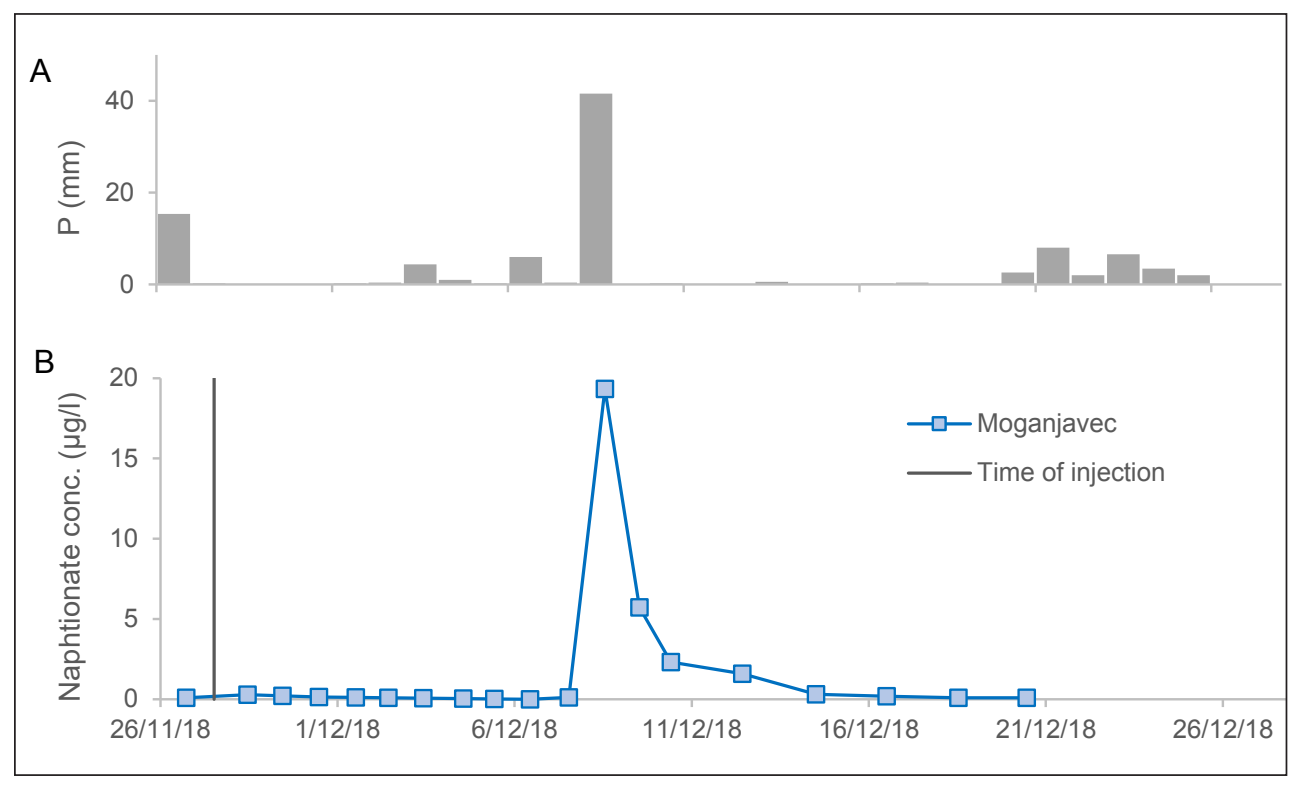

Fig. 12: A) Precipitation (P) at the ARSO Škocjan station; B) the measured naphthionate concentrations in the Moganjavec spring in the village of Dolina/San Dorligo near Trieste.

mately $5 \%$ of the tracer passed through the Boljunec/ Bagnoli spring, and approximately 25\% through the Osapska Reka spring. The smaller proportions of recovered tracer were anticipated on account of injection into the borehole and the poorer properties of naphthionate compared to uranine.

The comparison of naphthionate concentrations in individual springs of Boljunec/Bagnoli indicates different characteristics (Fig. 11). Despite the deficiencies of the tracer used, it is possible to conclude that naphthionate was not detected in the Na placu/Abbeveratoio spring and the underground water connection between the T218 borehole and this spring doesn't exist. This finding is in agreement with the results of previous tracer tests (Gabrovšek et al. 2015) and supports the idea that the $\mathrm{Na}$ placu/Abbeveratoio spring is recharged from the area of Glinščica/Rosandra valley.

On the other hand, the appearance of naphthionate in the Moganjavec spring in the village of Dolina/San
Dorligo on the Italian side of the border is convincing. The highest concentration $19.3 \mu \mathrm{g} / \mathrm{L}$ was measured in a sample taken on 7 December 2018, i.e., before a distinct increase in discharge (Fig. 12). The concentrations gradually decreased until 11 December 2018; the values were very low before and after this flood pulse. In the measurements for uranine, the fluorescence values were constantly below the detection limit. As the sampling point represents only one part of the Moganjavec spring, it is not possible to assess the total flow rate and the proportion of recovered tracer in this spring.

The maximum and peak velocity of the underground flow was calculated from the T2-18 borehole to the Boljunec/Bagnoli spring at $13 \mathrm{~m} / \mathrm{h}$, to the Osapska Reka spring at 11 and $10 \mathrm{~m} / \mathrm{h}$, and to the Moganjavec spring at 12 and $11 \mathrm{~m} / \mathrm{h}$ (Tab. 5).

In all the other monitored points, the naphthionate concentrations were not high enough to confirm a connection to the T2-18 borehole.

Tab. 5: Naphthionate appearance; $L$ - linear distance between injection point and sampling point; $t_{1}$ - time interval from injection to the first tracer detection; $v_{\max }-$ maximum flow velocity; $c_{\max }$ - highest measured tracer concentration; $t_{p}$ - time interval from injection to recording the highest tracer concentration; $v_{p}$ - peak velocity; $R$ - estimated proportion of recovered tracer.

\begin{tabular}{|l|l|l|l|l|l|l|l|}
\hline Naphthionate & $\mathrm{L}(\mathrm{km})$ & $\mathrm{t}_{1}(\mathrm{~h})$ & $\mathrm{v}_{\max }(\mathrm{m} / \mathrm{h})$ & $\mathrm{c}_{\max }\left(\mathrm{mg} / \mathrm{m}^{3}\right)$ & $\mathrm{t}_{\mathrm{p}}(\mathrm{h})$ & $\mathrm{v}_{\mathrm{p}}(\mathrm{m} / \mathrm{h})$ & $\mathrm{R}(\%)$ \\
\hline Boljunec/Bagnoli & 3.5 & 270 & 13 & 6.9 & 277 & 13 & $\sim 5$ \\
\hline Osapska Reka & 3.1 & 297 & 11 & 3.5 & 316 & 10 & $\sim 25$ \\
\hline Moganjavec & 2.6 & 214 & 12 & 19.3 & 240 & 11 & $\sim 0.1$ \\
\hline
\end{tabular}




\section{CONCLUSIONS}

In light of the vulnerability of karst water sources, a comprehensive analysis of the characteristics and dynamics of groundwater flow in their recharge areas should be performed prior to starting construction of traffic routes. Water in karst systems may flow from a single point towards multiple springs in different directions. The underground pathways and the location of the watersheds between the catchment areas of individual springs may also change depending on the hydrological conditions. This should be taken into consideration while planning regular monitoring and implementing measures in the event of a possible accident. For the assessment of groundwater drainage patterns along the proposed routes, tracer tests with artificial tracers are especially useful.

Several tracer tests have been conducted in the area in question, but especially the older ones were not tied to the planned construction of a new railway line. Regardless, they provide important information for assessing the potential impact of its construction and operation. Based on the collected older data and the findings of the new tracer test, the main characteristics of the flow of water in the karst area of the railway route between Divača and Koper/Capodistria can be summed up. From the area of the northern T1 tunnel the underground flow is directed through the aquifer of the Classical Karst mainly towards the Timava/Timavo springs in Italy. Through the most permeable conduits of the Reka-Timavo aquifers system the velocity of the water flow (calculated based on linear distance) ranges from 47 to $204 \mathrm{~m} / \mathrm{h}$ during different hydrological conditions. The new tracer test, in which uranine was injected into the stream in the Davorjevo brezno cave east of the T1 tunnel in late November 2018, has confirmed the main flow direction from the area of the T1 tunnel towards the Jama $1 \mathrm{v}$ Kanjaducah and Labodnica/Abisso di Trebiciano caves and onwards towards the Timava/Timavo springs. During medium-high water conditions the flow velocities along this system of interconnected and highly permeable karst fissures and conduits ranged from 30 to $50 \mathrm{~m} / \mathrm{h}$. Previous tracing in the T1-8 borehole has shown that a very small portion of groundwater also flows towards the springs in Boljunec/Bagnoli, but only from the southern part of the T1 tunnel and under favourable hydrological conditions.
In order to obtain additional information on the characteristics of the underground flow in the area of the southern T2 tunnel a different tracer was used for the tracing conducted in November 2018. The used tracer naphthionate proved to be less suitable for researching large karst systems. Furthermore, the results indicate that the amount of tracer injected was too low under the given conditions. Nevertheless, new information was obtained regarding the position and characteristics of the wide bifurcation zone between the springs of Rižana, Osapska Reka and Boljunec/Bagnoli. It has been confirmed that velocity and the dominant flow direction depend on the position within the tunnel. In the northern part, the groundwater flows mainly towards the springs Pri pralnici/Lavatoio and Jama/Antro di Bagnoli in Boljunec/Bagnoli, whereas no tracer was detected in the Na placu/Abbeveratoio spring. Towards the south the proportion of the flow towards the Rižana and Osapska Reka springs begins to increase. The flow velocities determined through various tracer tests range from 10 to $60 \mathrm{~m} / \mathrm{h}$.

As the tracer test was conducted in the cross-border Slovenian-Italian region and because the work was very demanding due to the hard-to-reach streams in deep karst caves and the large number of sampling points, the successful implementation of the test depended on the cooperation between the researchers and speleologists on both sides of the border. Due to the frequently long duration and high costs of tracer tests it was important to prepare in advance a detailed plan of the test and to adjust this plan to the real conditions during its implementation. The conclusions are beneficial to the monitoring of any potential negative impacts of the construction and operation of the new Divača - Koper/Capodistria railway line. For individual sections of the planned railway line, the most probable directions of the groundwater flow were determined and the times of possible occurrence of contamination in the springs were evaluated according to worst-case scenarios. As a basis for an early warning system, a monitoring scheme was established in which the dynamics of sampling are adapted to precipitation and hydrological conditions. The study example could also be useful for any further research on planning the hazard control of traffic routes in karst. 


\section{ACKNOWLEDGEMENTS}

This study was supported by the Slovenian Infrastructure Agency/Railways Division of the Ministry of Infrastructure. The authors acknowledge that the programme Karst Research, No. P6-0119, and the project Environmental effects and karst water sources: impacts, vulnerability and adaptation of land use, No. J6-8266, were financially supported by the Slovenian Research Agency, and the project Accordo attuativo di collaborazione, Individuazione e delimitazione degli acquiferi carsici del Friuli Venezia Giulia by the Geological Survey of the FVG Region. Our thanks go out to Matej Blatnik, Leon Drame, Franjo Drole, Franci Gabrovšek, Blaž Kogovšek, Cyril Mayaud, Mitja Prelovšek, Mateja Zadel (ZRC SAZU, Karst Research Institute), Sara Biolchi, Chiara Boccali, Christian Leone, Luca Terribili (Department of Mathematics and Earth Sciences, University of Trieste), Paolo de Curtis, Louis Torelli, Spartaco Savio,
Marco Armocida (Commissione Grotte E. Boegan), Grega Maffi, Tina Bizjak, Bogomir Remškar, Mitja Mršek, Jerica Koren, Miha Staut, Ines Klinkon, Matej Zalokar, Boštjan Vrviščar (Spelelogical Association of Slovenia), Edgardo Mauri, Davio Fabris, Paolo Camerino, Paolo Cossi, Francesco Degrassi, Enrico Iuorio, Piero Slama, Giuseppe Masarin, Alessandra Mautone, Mauro Cattarini, Dennis Dugulin, Claudio Bratos, Giulio Dagostini, Bruno Vojtissek, Manuel Laspada (Società Adriatica di Speleologia), who were involved in the injection, sampling and analyses alongside the authors of the article; to Darija Bak, Edi Zobec and Rižanski vodovod Koper for their assistance in organizing sampling on their properties; to Joerg Prestor for his participation in the discussion regarding which injection points to choose; and to Mitja Prelovšek for providing the data on the flow rates in Jama $1 \mathrm{v}$ Kanjaducah.

\section{REFERENCES}

Alija, S., Torrijo, F.J. \& M. Quinta-Ferreira, 2013: Geological engineering problems associated with tunnel construction in karst rock masses: the case of Gavarres tunnel (Spain).- Engineering geology, 157, 103-111. https://doi.org/10.1016/j. enggeo.2013.02.010

ARSO, 2019: Slovenian Environment Agency, Interactive weather.- [Online] Available from: https://meteo. arso.gov.si/met/en/app/webmet/ [Accessed 16th February 2019].

ARSO, 2020: Slovenian Environment Agency, Archive hydrological data.- [Online] Available from: http:// vode.arso.gov.si/hidarhiv/pov_arhiv_tab.php [Accessed 6th January 2020].

Atlas okolja, 2020: Environmental Atlas, Tracer tests data.- [Online] Available from: http://gis.arso.gov. si/atlasokolja/profile.aspx?id=Atlas_Okolja_AXL@ Arso [Accessed 20th January 2020].

Benischke, R., Goldscheider, N. \& C. Smart, 2007: Tracer techniques.- In: Goldscheider, N. \& D. Drew (eds) Methods in karst hydrogeology. Taylor\&Francis, pp. 161-184, London.

Boegan, E., 1938: Il Timavo. Studio sullidrologia carsica subaerea e sotterranea.- Mem. Ist. It. Speleol., pp. 251, Trieste.

Barberá, J.A., Mudarra, M., Andreo, B. \& B. De la Torre, 2018: Regional-scale analysis of karst underground flow deduced from tracing experiments: examples from carbonate aquifers in Malaga province, southern Spain.- Hydrogeology Journal, 26, 23-40. https://doi.org/10.1007/s10040-017-1638-5

Calligaris, C., Mezga K., Slejko F.F., Urbanc J. \& L. Zini, 2018: Groundwater characterization by means of conservative $\left(\mathrm{d}^{18} \mathrm{O}\right.$ and $\left.\mathrm{d}^{2} \mathrm{H}\right)$ and non-conservative $\left({ }^{87} \mathrm{Sr} /{ }^{86} \mathrm{Sr}\right)$ isotopic values: the Classical Karst Region aquifer case (Italy-Slovenia).- Geosciences, 8, 9, 321. https://doi.org/10.3390/geosciences8090321

Calligaris, C., Galli M., Gemiti F., Piselli S., Tentor M., Zini L. \& F. Cucchi, 2019: Electrical Conductivity as a tool to evaluate the various recharges of a Karst aquifer.- Rendiconti Online della Società Geologica Italiana, 47, 13-17. https://doi.org/10.3301/ ROL.2019.03

Cucchi, F., Zini, L. \& C. Calligaris (eds), 2015: Le acque del Carso Classico / Vodonosnik klasičnega Krasa. Progetto/Projekt HYDROKARST.- Edizioni Università di Trieste, pp. 181, Trieste.

Gabrovšek, F., Knez, M., Kogovšek, J., Mihevc, A., Mulec, J., Otoničar, B., Perne, M., Petrič, M., Prelovšek, M., Slabe, T., Šebela, S., Turk, J. \& N. Zupan Hajna, 2015: The Beka-Ocizla Cave System (Cave and Karst Systems of the World).- Springer, pp. 102, Cham [etc.]. https://doi.org/ 10.1007/978-3-319-04456-9_2

Galli, M., 2012: I traccianti nelle ricerche sul Timavo.Edizioni Università di Trieste, pp. 253, Trieste.

Gemiti, F., 1984a: La portata del Timavo alle risorgive di 
S. Giovanni di Duino.- Annali del Gruppo Grotte dell'Associazione XXX Ottobre, 7, 23-41.

Gemiti, F., 1984b: Nuova e originale prova di marcatura delle acque del Timavo.- Annali del Gruppo Grotte dell'Associazione XXX Ottobre, 7, 43-62.

Gemiti, F., 1995: Portata liquida e portata solida del Timavo alle risorgive di S. Giovanni di Duino.- Hydrores, $13,75-88$.

Gemiti, F., 1998: Marcatura delle acque del Timavo a seguito di un versamento di idrocarburi nella valle della Recca e interpretazione dellevento mediante l'utilizzo di dati meteorologici, idrologici, idrochimici.- Annali del Gruppo Grotte dell'Associazione XXX Ottobre, 10, 93-104.

Gemiti, F., 2004:Lesorgenti Sardosel'approvvigionamento idrico della Provincia di Trieste.- Atti e Memorie della Commissione Grotte "E. Boegan", 39, 67-80.

Goldscheider, N., Hötzl, H. \& K. Kottke, 2001: Microbiological decay of naphthionate in water samples as a source of misinterpretation of tracer tests.- In: Seiler, K.P. \& S. Wöhnlich (eds.) Characterizing Groundwater Flow: Proceedings of the XXXI IAH Congress, $10^{\text {th }}-14^{\text {th }}$ September 2001, Munich. CRC Press, 7781, Munich.

Goldscheider, N., Meiman, J., Pronk, M. \& C. Smart, 2008: Tracer tests in karst hydrogeology and speleology.- International Journal of Speleology, 37, 2740. https://doi.org/10.5038/1827-806X.37.1.3

Hötzl, H., 1999: Industrial and urban produced impacts.In: Drew, D. \& H. Hötzl (eds.) Karst hydrogeology and human activities, Impacts, consequences and Implications. International contributions to hydrogeology, A.A. Balkema, pp. 81-185, Rotterdam.

Jin, X., Li, Y., Luo, Y. \& H. Lui, 2016: Prediction of city tunnel water inflow and its influence on overlain lakes in karst valley.- Environmental Earth Sciences, 75, 1162. https://doi.org/10.1007/s12665-016$5949-\mathrm{y}$

Jurkovšek, B., Biolchi, S., Furlani, S., Kolar-Jurkovšek, T., Zini, L., Jež, J., Tunis, G., Bavec, M. \& F. Cucchi, 2016: Geology of the Classical Karst Region (SW Slovenia - NE Italy).- Journal of maps, 12, S1, 352362. http://dx.doi.org/10.1080/17445647.2016.1215 941

Käss, W., 1998: Tracing technique in geohydrology.- A.A, Balkema, pp. 581, Brookfield, Rotterdam.

Knez, M., Umek, U., Gabrovšek, F., Mihevc, A., Mulec, J., Otoničar, B., Petrič, M., Pipan, T., Prelovšek, M., Ravbar, N., Slabe, T., Šebela, S., Zupan Hajna, N., Blatnik, M., Kogovšek, B., Kukuljan, L., Mayaud, C., Aljančič, M., Drame, L., Drole, F. \& M. Zadel, 2019: Krasoslovna interpretacija raziskav : zbirno poročilo : izvedba dopolnilnih strukturno geoloških, hidrogeoloških, krasoslovnih in geotehniških raziskav za PZI drugega tira železniške proge med Divačo in Koprom : drugi tir železniške proge Divača-Koper.Gradbeni inštitut ZRMK, Ljubljana.

Kogovšek, J., 2011: Threats to the karst water sources from traffic in normal conditions.- In: Knez, M. et al. (eds.) Karstology and development challenges on karst, Water. ZRC Publishing, pp. 47-64, Ljubljana.

Kogovšek, J. \& M. Petrič, 2004: Advantages of longerterm tracing - three case studies from Slovenia.Environmental Geology, 47, 76-83. https://doi. org/10.1007/s00254-004-1135-8

Kogovšek, J. \& M. Petrič, 2011: Spillages of hazardous substances endanger karst waters.- In: Knez, M. et al. (eds.) Karstology and development challenges on karst, Water. ZRC Publishing, pp. 76-83, Ljubljana.

Krivic, P., Bricelj, M., Trišič, N. \& M. Zupan, 1987: Sledenje podzemnih vod v zaledju izvira Rižane.Acta carsologica, 16, 83-104.

Krivic, P., Bricelj, M. \& M. Zupan, 1989: Podzemne vodne zveze na področju Čičarije in osrednjega dela Istre.- Acta carsologica, 18, 265-295.

Li, X. \& Y. Li, 2014: Research on risk assessment system for water inrush in the karst tunnel construction based on GIS: case study on the diversion tunnel groups of the Jinping II Hydropower Station.- Tunnelling and Underground Space Technology, 40, 182-191. https://doi.org/10.1016/j.tust.2013.10.005

Mesarec, D., 2011: Davorjevo brezno.- Jamar, 7, 20-26.

Massei, N., Wang, H.Q., Field, M.S., Dupont, J.P., Bakalowicz, M. \& J. Rodet, 2006: Interpreting tracer breakthrough tailing in a conduit-dominated karstic aquifer.- Hydrogeology Journal, 14, 6, 849-858. https:// doi.org/10.1007/s10040-005-0010-3

Meus, P., Käss, W. \& P.A. Schnegg, 2006: Background and detection of fluorescent tracers in karst groundwater-- Hidrogeologia y Aguas Subterraneas, 18, 65-75.

Meus, P., Schnegg, P.A., Frippiat, C. \& J. Monfort, 2014: Promises and limitations in the use of sulfonates colourless tracers in hydrogeology.- Geologica Belgica, 17, 1, 90-95.

Mosetti, F., 1965: Nuova interpretazione di un esperimento di marcatura radioattiva del Timavo.- Bolletino di Geofisica teorica et applicata, 7, 27, 218-243.

Peric, B., 2012: Karst water course tracing between ponor and springs: the Reka river example, Kras/Carso, SW Slovenia-NE Italy.- In: Šebela S., Peric B., Fabbricatore A. \& D. Cergna (eds.) International Congress on "Scientific Research in Show Caves", 13th to 15th September 2012 Postojna, pp. 32-33.

Petrič, M. \& J. Kogovšek, 2011: Assessment of the possible impact of the construction of the Divača-Koper rail-way line on the quality of karst waters.- In: 
Prelovšek, M. et al. (eds.) Pressures and protection of the underground karst: cases from Slovenia and Croatia. Karst Research Institute ZRC SAZU, pp. 138-146, Postojna.

Placer, L., Vrabec, M. \& B. Celarc, 2010: The bases for understanding of the NW Dinarides and Istria Peninsula tectonics.- Geologija, 53, 1, 55-86. https://doi. org/10.5474/geologija.2010.005

Raithel, M., Baumbusch, J. \& S. Kielbassa, 2016: Construction of the New High-Speed Railway Line Ulm-Wendlingen in Karstifed Rock.- Procedia engineering, 143, 1144-1151. https://doi.org/10.1016/j. proeng.2016.06.139

Stevanović, Z., 2019: Karst waters in potable water supply: a global scale overview.- Environmental Earth Sciences, 78, 662. https://doi.org/10.1007/s12665019-8670-9

Timeus, G., 1928: Nei misteri del mondo sotterraneo.Alpi Giulie, 29, 1-38.

Turpaud, P., Zini, L., Ravbar, N., Cucchi, F., Petrič, M. \& J. Urbanc, 2018: Development of a Protocol for the Karst Water Source Protection Zoning: Application to the Classical Karst Region (NE Italy and SW Slovenia).- Water Resources Management, 32, 1953-1968. https://doi.org/10.1007/s11269-017$1882-4$

Urbanc, J., Mezga, K. \& L. Zini, 2012: An assessment of capacity of Brestovica - Klariči Karst Water Supply (Slovenia).- Acta carsologica, 41, 1, 89-100. https:// doi.org/10.3986/ac.v41i1.50
Vincenzi, V., Gargini, A., Goldscheider, N. \& L. Piccinini, 2014: Differential Hydrogeological Effects of Draining Tunnels Through the Northern Apennines, Italy.- Rock Mechanics and Rock Engineering, 47, 947965. https://doi.org/10.1007/s00603-013-0378-7

Zhou, W. \& B.F. Beck, 2005: Roadway construction in karst areas: management of stormwater runoff and sinkhole risk assessment.- Environmental Geology, 47, 1138-1149. https://doi.org/10.1007/s00254-0051252-Z

Zini L., Visintin L., Cucchi F. \& W. Boschin, 2011: Potential impact of a proposed railway tunnel on the karst environment: The example of Rosandra valley, Classical Karst Region, Italy-Slovenia.- Acta carsologica, 40, 1, 207-218. https://doi.org/10.3986/ac.v40i1.38

Zini L., Calligaris C. \& E. Zavagno, 2014: Classical Karst hydrodynamics: a shared aquifer within Italy and Slovenia.- In: Castellarin, A. et al. (eds.) Evolving Water Resources Systems: Understanding, Predicting and Managing Water-Society Interactions. International Association of Hydrological Sciences Publication, 364, pp. 499-504. https://doi.org/10.5194/ piahs-364-499-2014

Zini, L., Calligaris, C. \& F. Cucchi, 2015: The challenge of tunnelling through Mediterranean karst aquifers: the case study of Trieste (Italy).- Environmental Earth Sciences, 74, 281-295. https://doi. org/10.1007/s12665-015-4165-5 